\title{
Effect of Rates and Time of Nitrogen Application on Growth, Yield, and Yield Components of Wheat (Triticum aestivum L.) in Eastern Hararghe, Ethiopia
}

\author{
Yohannes Erkeno $^{1} \quad$ Nigussie Dechassa ${ }^{2}$ \\ 1.Wachemo University College of agriculture department of plant science \\ 2. Haramaya university college of agriculture
}

\begin{abstract}
Wheat is a highly valued crop in the national diet of Ethiopians, and widely produced in the country. However, its productivity is constrained by low plant-available soil nitrogen due to depleting soil organic matter content and high leaching losses of mineralized nitrogen during the rainy seasons. This problem is compounded by low rates and inappropriate-timing of $\mathrm{N}$ fertilizer applications in the country. Therefore, field experiments were carried out during the 2013 main cropping season from July to November in Meta and Haramaya districts of eastern Ethiopia on a farmer's field and on the research field of Haramaya University, respectively. The objectives of the study was to investigate the effect of rate and time of nitrogen application on growth, yield, grain protein content, and $\mathrm{N}$ use efficiency of bread wheat. The treatments consisted of six levels of nitrogen $(0,46,69,92,115$ and $138 \mathrm{~kg} \mathrm{~N} \mathrm{ha-}$ $\left.{ }^{1}\right)$ and four application times $(1 / 2$ dose at planting $+1 / 2$ dose at mid-tillering; $1 / 2$ dose at mid-tillering $+1 / 2$ at anthesis $; 1 / 3^{\text {rd }}$ dose each at planting, mid-tillering + anthesis, and $1 / 4^{\text {th }}$ dose at planting $+1 / 2$ dose at mid-tillering + $1 / 4^{\text {th }}$ dose at anthesis. The experiments were laid out in factorial arrangement in RCBD with three replications. All the parameters evaluated were affected by the main effect of $\mathrm{N}$ fertilizer rate and time of $\mathrm{N}$ application. However, grain yield, harvest index, hectolitre weight, number of kernels per spike, total biomass yield, and total number of tillers at Haramaya and harvest index, were not significantly affected by the time of $\mathrm{N}$ fertilizer application. Days to heading and physiological maturity were prolonged in response to increasing the rate of nitrogen application at both sites. The highest biomass yield and plant height were recorded at $138 \mathrm{~kg} \mathrm{~N} \mathrm{ha}^{-1}$ at both sites. Most of the parameters including grain yield exhibited maximum performances under this rate of $\mathrm{N}$ supply. The highest spike length was obtained at split application of $138 \mathrm{~kg} \mathrm{~N} \mathrm{ha}^{-1}$ applied $\left(1 / 4^{\text {th }}\right.$ dose at planting, $1 / 2$ at mid-tillering and $1 / 4^{\text {th }}$ at anthesis). Similarly, the tallest plants were recorded under similar rate $\mathrm{N} \mathrm{ha}^{-1}$ applied $(1 / 2$ dose at planting and $1 / 2$ dose at anthesis) at Haramaya. The nitrogen use efficiency decreased with increased $\mathrm{N}$ rate at both sites. In general, at Haramaya, plots treated with 46 and $115 \mathrm{~kg} \mathrm{~N} \mathrm{ha}^{-1}$ at two equal splits at mid-tillering and at anthesis produced high grain yields, coupled with the best economic benefit or profitability. Whereas, at Meta, plots treated with 46 and $92 \mathrm{~kg} \mathrm{~N} \mathrm{ha}^{-1}$ at two equal splits at mid-tillering and at anthesis and at three splits $\left(1 / 4^{\text {th }}\right.$ at planting $+1 / 2$ at mid-tillering $+1 / 4^{\text {th }}$ at anthesis), respectively produced optimum grain yields, coupled with the best economic benefit or profitability. It could, thus, be concluded that application of 46 and $115 \mathrm{~kg} \mathrm{~N}^{-1}$ in two splits at midtillering and at anthesis and $92 \mathrm{~kg} \mathrm{~N} \mathrm{ha}^{-1}$ in three splits $\left(1 / 4^{\text {th }}\right.$ at planting $+1 / 2$ at mid-tillering $+1 / 4^{\text {th }}$ at anthesis) enhanced yield, yield components and $\mathrm{N}$ use efficiency of bread wheat. This implies the change of the blanket recommendation of $64 \mathrm{~kg} \mathrm{~N} \mathrm{ha}^{-1}$ in the study area to this rate and time of application to improve the yield and $\mathrm{N}$ use efficiency of the crop in the study area.
\end{abstract}

Keywords:- nitrogen fertilizers, yield and wheat

DOI: $10.7176 / \mathrm{JNSR} / 9-11-01$

Publication date:June $30^{\text {th }} 2019$

\section{INTRODUCTION}

Wheat (Triticum aestivum L.) was among the first of the domesticated food crops and it has been the basic staple food for most of the world for more than 10,000 years. It is the most widely grown cereal crop in the world and one of the central pillars of global food security. About 650 million $\mathrm{t}$ of wheat was produced worldwide on 217 million ha in 2010 with a productivity level of about $3 \mathrm{t} \mathrm{ha}^{-1}$ (FAO, 2012). Wild relatives of the crop first grew in the Middle East about 11,000 years ago. By about 4,000 B.C. wheat farming had spread in Asia, Europe and Northern Africa. New species of wheat gradually developed as a result of the accidental breeding of cultivated wheat with wild grasses (World Book Encyclopedia, 1993).

Wheat is an important cereal crop in Ethiopia that is widely cultivated in a wide range of altitude (Hailu, 1991). In Ethiopia, it is grown annually on 1.63 million hectares with a total production of 3.44 million tons, which makes the country the largest wheat producer in Sub-Saharan Africa (CSA, 2012). It is the main staple food for about $36 \%$ of the Ethiopian population (CSA, 2004; CIMMYT, 2005). Wheat ranks fourth in area coverage after (Tef, Maize and Sorghum) and $3^{\text {rd }}$ in total production after maize and tef. The national average yield of the crop was estimated to be 2.11 tons ha-1, which is very low compared to the World's average yield of $3 \mathrm{t} \mathrm{ha}^{-1}\left(\mathrm{CSA}_{\text {, }}\right.$ 2012). In Ethiopia, under improved production technologies grain yield ranges from 3-6 tha ${ }^{-1}$ and at research 
center it goes up to 5-7 $\mathrm{t} \mathrm{ha}^{-1}$. This indicates the existing gap between potential yield and yield at farmers' level (Bekele et al., 1993).

Cereal grains are major contributors to human nutrition throughout much of the world (Hoveland, 1980; Gallagher, 1984), and comprise about $78.17 \%$ and $84.96 \%$ of total crop production and area coverage, respectively, in Ethiopia (CSA, 2012). Grain protein composition, is an important of wheat grain quality and is probably the trait most commonly used to estimate it, since it is considered to be of great importance for bread quality and human nutrition. It is also well known that $\mathrm{N}$ fertilizer applications enhance wheat grain protein content and its energy source. In Ethiopia, however, due to low quality and traditional cereal diets, especially poor people suffer from protein and energy deficiencies (Abera Bekele, 1991). Currently, wheat is one of the major cereals of choice in the country, dominating food habits of the highland population. Therefore, it is highly important to enhance the quality and quality of the product through proper crop nutrition. Nutritionally, bread wheat grain is high in carbohydrates: whole grain wheat flour contains roughly $70 \%$ carbohydrate, $11.5 \%$ protein (varying from $8-15 \%$ ), $2 \%$ fat, $2 \%$ fibre, $1.5 \%$ ash, and $13 \%$ water (Hoveland, 1980 ).

The national mean grain yield of wheat is low due to the use of unimproved varieties; poor weed management practices, the prevalence of aggressive and virulent crop pathogens, depletion of soil nutrients, low level of chemical fertilizer usage, and the unavailability of other modern crop management inputs (Hoveland, 1980). Application of fertilizer greatly increases grain yields, and facilitates the adoption of improved high-yielding varieties. This practice is also taken as a major characteristic of modern farm input usage in the country-even though the rate of adoption is relatively low (Holmburg, 2000). Therefore, greater usage of chemical fertilizer has been advocated as a primary means of increasing wheat grain yield in Ethiopia.

The result of multi-location $\mathrm{N}$ fertilizer trials conducted in the highlands of south eastern Ethiopia indicated that split application of $\mathrm{N}$, one third rates at planting and the rest two third at mid-tillering, provided optimum wheat yield (Tilahun Gelato et al., 2008). In other parts of the country it was reported that split application of nitrogen at planting and tillering (when nitrogen rates greater than $30 \mathrm{~kg} \mathrm{~N} \mathrm{ha-1}$ ) had shown significant improvement in wheat yield (Tilahun Gelato et al., 1996)

Nitrogen is the key nutrient in plant growth and the most often deficient nutrient markedly affecting plant growth (Miller and Donahue, 1997). Crop response to nitrogen fertilizer varies with rate and time of application in relation to plant development. It is an essential constituent of cell wall, cytoplasmic proteins, nucleic acids (the regenerative portions of the living cell), chlorophyll and a vast array of other cell components. Therefore, a low supply of $\mathrm{N}$ has a profound influence on crop growth and may lead to a great loss in grain yield (Miller and Donahue, 1997).

Nitrogen fertilizer applied at the correct time and in the right amount to an actively growing crop will result in optimum yield and very little $\mathrm{NO}_{3}{ }^{-}$will remain in the soil at harvest minimizing risk of loss by leaching (Johnston, 1994). On the other hand, luxuriant application of $\mathrm{N}$ fertilizer at sowing increased the flush emerging broad leaf weeds, thereby increasing the labour requirements for hand weeding. Hence, split application of nitrogen was considered more economical both in terms of weed management under farmers' conditions and as a risk aversion strategy, efficient nitrogen use for optimizing grain yield and lowering grain protein with lower nitrogen inputs. Split nitrogen application prior to stem elongation with top-dressing can increase fertilizer nitrogen recovery whilst maintaining or increasing nitrogen use efficiency compared with all-fall application (Tanner et al., 1992).

In general, high levels of $\mathrm{N}$ supply result in a higher protein content, but increased efficiency of utilization is realized when concentration in the kernels increases and grain yield remains stable (Ortiz-Monasterio et al., 2002). Reports have shown that about $50 \%$ of applied $\mathrm{N}$ fertilizer remains unavailable to a crop due to $\mathrm{N}$ losses (Zafar and Muhammad, 2007).

Wheat provides more protein than any other cereal crops (Iqtidar et al., 2006). However, the global challenge for wheat nutrition is to increase grain yield while maintaining its protein (Tilman et al., 2002). Low soil fertility, especially nitrogen $(\mathrm{N})$ deficiency, is one of the major constraints limiting wheat production in Ethiopian highlands (Tanner et al., 1993). Thus, increased usage of $\mathrm{N}$ fertilizer is considered to be a primary means of increasing wheat grain yield and protein content in these areas.

According to Ali et al. (2005), higher wheat grain yield was produced where nitrogen was applied at the higher rates $\left(70,140\right.$ and $\left.210 \mathrm{~kg} \mathrm{~N} \mathrm{ha}^{-1}\right)$, which were found statistically significant compared to the treatment where $\mathrm{N}$ was not applied. Other researchers (Tanner et al., 1999) have concluded that increasing $\mathrm{N}$ levels promote growth and development, which ultimately reflects grain yield. In the highlands of south eastern Ethiopia, $138 \mathrm{~kg}$ $\mathrm{N}$ ha $^{-1}$ was reported as economic optimum $\mathrm{N}$ fertilizer rate for the semi-dwarf bread wheat cultivar HAR-1685 (Tanner et al., 1999). It was indicated that higher $\mathrm{N}$ application rates for the cultivar provided a return on the investment in fertilizer in excess of $300 \%$ and an additional $12 \mathrm{~kg}$ grain for each $\mathrm{kg}$ of $\mathrm{N}$ applied. However, farmers usually apply suboptimal $\mathrm{N}$ rates (less than $100 \mathrm{~kg} \mathrm{~N} \mathrm{ha}^{-1}$ ) in Ethiopia. The results from the experiment conducted by Ali et al. (2005) revealed that application of $\mathrm{N}$ at the rate of $210 \mathrm{~kg} \mathrm{ha}^{-1}$ gave the highest grain yield $\left(4.77 \mathrm{t} \mathrm{ha}^{-}\right.$ $1)$. 
In Meta District, farmers use DAP and Urea fertilizer which contains $18 \% \mathrm{~N}$ and $46 \% \mathrm{P}_{2} \mathrm{O}_{5}$ and $46 \% \mathrm{~N}$ respectively. Nitrogen fertilizer is highly soluble and once applied to the soil may be lost from the soil plant system or made unavailable to plants through the processes of leaching, $\mathrm{NH}_{3}$ volatilization, denitrification, $\mathrm{NH}_{4}^{+}$fixation and $\mathrm{N}$ immobilization (Bock, 1984). Moreover, $\mathrm{N}$ is required in large quantities than other nutrients. In order to develop sustainable crop production practice, it is essential to understand the rate of applied $\mathrm{N}$ in the soil plant system of different production environments. Therefore, based on the nature and importance of $\mathrm{N}$ nutrient for wheat crop, it was important to developed site specific $\mathrm{N}$ fertilizer recommendation other than blanket recommendation.

Furthermore, Legg and Meisinger (1982) reported that not more than 50 to $60 \%$ of applied $\mathrm{N}$ is usually recovered under average field conditions, and efficient timing and placement of $\mathrm{N}$ could increase recovery of applied $\mathrm{N}$ up to 70 or to $80 \%$. Most studies on bread wheat in Ethiopia have been conducted with blanket (100 kg $\mathrm{N} \mathrm{ha}^{-1}$ ) recommendations but in eastern Hararghe $64 \mathrm{~kg} \mathrm{~N}^{-1}$ (MOA, 2009) have been recommended. Besides, wheat is grown during high rainfall season and losses of applied $\mathrm{N}$ through leaching may be an issue to be tackled through proper rate and timing of $\mathrm{N}$ fertilizer application. In view of this, the study was conducted on the following objectives

\section{Objective of the study}

- to study the effects of rates and time of application of nitrogen fertilizer on the growth, yield components, yield, and grain protein of bread wheat;

\section{MATERIALS AND METHODS}

\subsection{Description of the Study Area}

The experiment was conducted at two sites, i.e. at the main campus of Haramaya University on-station and farmer's field in Meta District (Dursitu Bilisuma kebele) of eastern Hararghe zone of Oromia Regional State from July to November during the main cropping season of 2013. Meta district is located in the eastern central part of West Hararghe zone. The experimental field has an area of $378 \mathrm{~m}^{2}$, i.e. about $63.6 \%$ of the total area and is located at $9^{0} 24^{\prime} \mathrm{N}$ latitude and $41^{0} 35^{\prime} \mathrm{E}$ longitude at an altitude of 2227 metres above sea level. It is located at $450 \mathrm{~km}$ away from Addis Ababa on the road to Harare and characterized by annual rainfall of 700 to $1100 \mathrm{~mm}$ and mean maximum and minimum temperature of $18{ }^{\circ} \mathrm{C}$ and $14.5^{\circ} \mathrm{C}$, respectively. It is classified into dega, woina dega and kola agroclimatic zones with erratic and highly variable rainfall both temporally and spatially. Luvi-sols characterized by clay, sandy loam and clay loam with a $\mathrm{pH}$ of 7.66 are the major soil types found in the district.

Haramaya is located at the distance of $512 \mathrm{~km}$ away from Addis Ababa. It is situated at $9^{0} 26^{\prime} \mathrm{N}$ latitude, $42^{0} 30^{\prime} \mathrm{E}$ longitude and at the altitude of 1980 metres above sea level. The site receives a mean annual rainfall of $780 \mathrm{~mm}$, with a mean minimum and maximum temperature of $8.25^{\circ} \mathrm{C}$ and $23.4{ }^{\circ} \mathrm{C}$, respectively. Soil type of this site is silty clay loam with a $\mathrm{pH}$ of 8.12 .

\subsection{Experimental Materials \\ 3.3 Planting material}

Bread wheat variety 'Danda'a' which was developed and released by Kulumsa Agricultural Research Centre (KARC) in 2010 was used as a test crop. It is a high yielding white-seeded variety adapted to a wide range of altitudes (mid to highland) areas. Days to heading, days to physiological maturity and plant height of bread wheat are 56-80, 110-145 and 90-113, respectively. The yield potential of the Danda'a at farmers' fields produces 2500$5000 \mathrm{~kg} \mathrm{ha}^{-1}$ and it is resistant to leaf rust.

\subsection{Fertilizer material}

[Urea $(46 \% \mathrm{~N})$, and TSP $\left(46 \% \mathrm{P}_{2} \mathrm{O}_{5}\right)$ ] were used as a source of nitrogen and phosphorus nutrient elements.

\subsection{Treatments and Experimental Design}

The treatments consisted of six levels of nitrogen $\left(0,46,69,92,115\right.$ and $\left.138 \mathrm{~kg} \mathrm{~N} \mathrm{ha}^{-1}\right)$ and four split $\mathrm{N}$ applications in the season. The times of $\mathrm{N}$ application were adjusted according to (Zadoks et al., 1974) decimal growth stage for wheat. Accordingly, the timings of $\mathrm{N}$ application were adjusted as follows: $\mathrm{T}_{1}(1 / 2$ dose at planting $+1 / 2$ dose at mid tillering); $T_{2}(1 / 2$ dose at mid tillering $+1 / 2$ dose at anthesis $) ; T_{3}(1 / 3$ dose at planting $+1 / 3$ dose at mid tillering $+1 / 3$ dose at anthesis); $T_{4}(1 / 4$ dose at planting $+1 / 2$ dose at mid tillering $+1 / 4$ dose at anthesis). One additional control treatment consisting of $0 \mathrm{~kg} \mathrm{~N} \mathrm{ha}^{-1}$ was included for comparison.

Consequently, the experiment was laid out in randomized complete block design (RCBD) with factorial arrangements of $5 \times 4=20$ treatment combinations together with the one control treatment, making a total of 21 treatments, which were replicated three times. The size of each plot was $2 \mathrm{~m}$ x $3 \mathrm{~m}\left(6 \mathrm{~m}^{2}\right)$ and the distance between the plots and blocks were kept at $0.5 \mathrm{~m}$ and $1 \mathrm{~m}$ apart, respectively. Seeds were sown into rows of $0.2 \mathrm{~m}$ apart and 
$3 \mathrm{~m}$ long. Each plot consisted of 10 rows. The net central unit areas of each plot consisting of 6 central rows of 2 $\mathrm{m}$ length each $\left(2.4 \mathrm{~m}^{2}\right)$ were used for data collection and measurement.

\subsection{Management of the Experiment}

The experimental field was prepared following the standard production (conventional tillage) practices before planting the wheat varieties. In accordance with the specifications of the design, a field layout was prepared and each treatment was assigned randomly to experimental plots within a block. After the seedbeds were levelled, the seed was sown at the recommended rate of $150 \mathrm{~kg} \mathrm{seed} \mathrm{ha}^{-1}$. Planting was done at the last week of the month of 24, July 2013 and 19, July 2013 at Haramaya and Meta, respectively, by uniformly drilling the seeds in to the rows made by hand hoes. Phosphate fertilizer in the form of TSP $\left(46 \% \mathrm{P}_{2} \mathrm{O}_{5}\right)$ at the recommended rate of $46 \mathrm{~kg} \mathrm{P}_{2} \mathrm{O}_{5}$ $\mathrm{ha}^{-1}$ was applied equally to all plots as basal application at planting. For the $\mathrm{N}$ application at planting urea was broadcasted and incorporated into the soil just before planting.

The second and third $\mathrm{N}$ fertilizer applications as dry urea were done by side dressing at the specified growth stages of the crop at the beginning of August and end of September, 2013, respectively. The crop was harvested on 29 November 2013 and early 04, December 2013 at Haramaya and Meta, respectively. Weeds were removed by hand according to the locally recommended practices, $21-25$ and $41-45$ days after emergence. Additionally, weeding out of late-emerging grasses was done to avoid interference with the wheat in the uptake of applied N. In order to manage the outbreak of leaf rust disease which often occurs in the area, fungicide (PYRINEX 48 EC) was applied at the rate of 0.5 litres ha ${ }^{-1}$ immediately at the start of disease appearance in the area. All field management and protection practices were applied as recommended for the crop.

\subsection{Soil Sampling and Analysis}

For soil analysis of the experimental land was, done. Soil samples were taken randomly in a zigzag pattern before planting. Twenty soil samples were taken from the entire experimental field using an augur to the depth of 0-30 $\mathrm{cm}$ from the top soil layer. The soil samples were composited into a bucket. Crumbs of the soil were broken into small pieces and thoroughly mixed. From this mixture, a sample weighing $1 \mathrm{~kg}$ was filled into a plastic bag. The soil was air-dried and sieved through a $2 \mathrm{~mm}$ sieve. The working samples obtained from each submitted samples were bagged, properly labeled and transported to the laboratory for analysis of selected physico-chemical properties following standard laboratory analysis methods.

In the laboratory, the pre-plant composite soil samples were used to determine organic carbon, total $\mathrm{N}$, soil $\mathrm{pH}\left(\mathrm{H}_{2} \mathrm{O}\right)$, available phosphorus, cation exchange capacity (CEC), Electrical Conductivity ( EC), Exchangeable Cations ( $\mathrm{K}, \mathrm{Na}, \mathrm{Ca} \& \mathrm{Mg}$ ) and texture. Accordingly, the soil $\mathrm{pH}$ was determined from the filtered suspension of 1:2.5 soils to water ratio using a glass electrode attached to a digital $\mathrm{pH}$ meter (potentiometer) (Page, 1982). Soil organic carbon content was determined by the wet digestion method as described by Walkley and Black (1954). Total nitrogen was determined using Kjeldhal method (Jackson, 1973). Available phosphorus was determined by extraction with $0.5 \mathrm{M} \mathrm{NaHCO}_{3}$ according to the methods of Olsen et al. (1954).

The total number of exchangeable cations a soil can hold, cation exchange capacity (CEC), was measured after saturating the soil with $1 \mathrm{~N}$ ammonium acetate $\left(\mathrm{NH}_{4} \mathrm{OAc}\right)$ and displacing it with $1 \mathrm{~N} \mathrm{NaOAc}$ (Chapman, 1965). Particle size distribution (soil texture) was done by hydrometer method (differential setting within a water column) according to FAO (2008) using particles less than $2 \mathrm{~mm}$ diameter. The procedure measures percentage of sand $(0.05-2.0 \mathrm{~mm})$, silt $(0.002-0.05 \mathrm{~mm})$ and clay $(<0.002 \mathrm{~mm})$ fractions in soils. Analysis of the soil was analyzed at JIJE Analytical Service Laboratory.

\subsection{Crop Data Collection and Measurements \\ 3.8.1 Phonological and growth parameters}

3.8.2 Days to 50\% heading: It was determined by counting the number of days from $50 \%$ emergence to heading (as $50 \%$ of the plants started to form panicles). Visual observation was used to determine heading of the plants.

3.8.3 Days to $90 \%$ physiological maturity: Days to physiological maturity was determined as the number of days from emergence to $90 \%$ maturity based on visual observation, which was indicated by senescence of the leaves as well as free threshing of seeds from the glumes when pressed between the thumb and the forefinger.

3.8.4 Plant height (cm):- it was measured at physiological maturity from the soil surface to the top of the spike (awns excluded) of 10 randomly taken plants from the net plot area.

3.8.5 Lodging index: The degree of lodging was assessed just before the time of harvest by visual observation based on the scales of $1-5$, where $1\left(0-15^{\circ}\right)$ indicates no lodging, $2\left(15-30^{\circ}\right)$ indicates $25 \%$ lodging, $3\left(30-45^{\circ}\right)$ indicates $50 \%$ lodging, $4\left(45-60^{\circ}\right)$ indicates $75 \%$ lodging and $5\left(60-90^{\circ}\right)$ indicates $100 \%$ lodging (Donald, 2004). The scale was determined by the angle of inclination of the main stem from the vertical line to the base of the stem by visual observation. 


\subsection{Yield Components and Yield}

3.9 .1 Total number of tillers: It was counted from the middle two rows of $0.5 \mathrm{~m}$ length per net plot at physiological maturity.

3.9 .2 Number of effective tillers (number $\mathbf{~ m}^{-2}$ ):- It was determined at maturity by counting all the spikes producing seeds in the two rows of $0.5 \mathrm{~m}$ length per net plot at physiological maturity.

3.9 .3 Kernels per spike (number spike ${ }^{-1}$ ):- the mean number of grains per spike was computed as an average of 10 randomly taken spikes from the central unit area, threshed, and grains were counted using an electronic seed counter.

3.9 .4 Above ground biomass yield ( $\left.\mathbf{k g ~ h a}^{-1}\right)$ :- plants in the net plot area were harvested at ground level and tied into bundles. Above ground biomass yield was recorded by weighing the bundles in the field using a sensitive balance after sun-drying to a constant weight.

3.9 .5 Grain yield ( $\mathbf{k g ~ h a}^{-1}$ ):- Grain yield was determined from the harvested net plot area of $2.4 \mathrm{~m}^{2}$. Grains were cleaned following harvesting and threshing, weighed using an electronic balance and the yield was adjusted to $12.5 \%$ moisture content as:

Grain yield $\left(\mathrm{kg} \mathrm{ha}^{-1}\right)$ at $12.5 \%$ moisture base $=$ Yield obtained $\left(\mathrm{kg} \mathrm{ha}^{-1}\right) \times(100-\% \mathrm{MC})$

Where, $\mathrm{MC}=$ grain moisture content

3.10 Harvest index: It was determined as the ratio of grain yield to the above ground dry biomass yield and expressed as a percentage.

$$
\text { Harvest index }(\%)=\frac{\text { Grain yield } / \text { plot }}{\text { Above ground dry biomass/plot }} \times 100
$$

\subsection{Statistical analysis}

The data were subjected to analysis of variance (ANOVA) using Genstat discovery $15^{\text {th }}, 4$ editions. Means with significant treatment effects were separated using the Tukey test at $5 \%$ level of significance.

\section{RESULTS AND DISCUSSION}

\subsection{Soil Physical and Chemical Properties of the Study Area before Planting}

Selected physical and chemical properties were analysed for composite surface soil $(0-30 \mathrm{~cm})$ samples collected from each replication before planting at both sites. The results at Haramaya and Meta indicated that textures of the soil in the experimental sites to be silty clay loam and clay, respectively (Table 1). The texture indicates the degree of weathering, nutrient and water holding capacity of the soil. High clay content may indicate the better water and nutrient holding capacity of the soil in the experimental site.

The available $P$ content of the soil at Haramaya and Meta have medium $P\left(12.36 \mathrm{mg} \mathrm{kg}^{-1}\right)$ and $(20.46 \mathrm{mg} \mathrm{kg}$ $\left.{ }^{1}\right)$, which are medium and high, respectively, according to the rating of Landon (1991). This means that $\mathrm{P}$ is limiting for Haramaya soil whereas it is sufficient for Meta soil for wheat production (FAO, 2008). The soil reaction of the experimental site is nearly neutral where the $\mathrm{pH}$ in 1:2.5 (weight volume ${ }^{-1}$ ) soil samples to $\mathrm{CaCl}_{2}$ solution were 8.12 and 7.66 at Haramaya and Meta, respectively. According to FAO (2008) suitable $\mathrm{pH}$ range for most crops is between 6.5 and 7.5 in which $\mathrm{N}$ availability is optimum. This indicates suitability of the soil $\mathrm{pH}$ in the experimental site for optimum crop growth and yield.

Table 1. Soil physical and chemical properties of the study area

\begin{tabular}{|c|c|c|c|c|c|c|c|c|c|}
\hline \multicolumn{10}{|c|}{ Haramaya } \\
\hline \multicolumn{4}{|c|}{ Physical Properties } & \multicolumn{6}{|c|}{ Chemical Properties } \\
\hline \multicolumn{2}{|c|}{$\begin{array}{l}\text { Particle size } \\
\text { Distribution (\%) }\end{array}$} & & $\begin{array}{c}\text { Textural } \\
\text { class }\end{array}$ & $\mathrm{pH}$ & $\begin{array}{l}\mathrm{OM} \\
(\%)\end{array}$ & $\begin{array}{l}\mathrm{OC} \\
(\%)\end{array}$ & $\begin{array}{r}\text { Total } \\
\text { N }(\%) \\
\end{array}$ & $\begin{array}{c}\text { Av.P } \\
(\mathrm{ppm})\end{array}$ & $\begin{array}{c}\text { CEC } \\
\mathrm{Cmol} \mathrm{kg}^{-1} \\
\end{array}$ \\
\hline Sand & Silt & Clay & Silty clay & & & & & & \\
\hline 17 & 43 & 40 & loam & 8.12 & 2.03 & 1.18 & 0.10 & 12.36 & 26.48 \\
\hline \multirow{2}{*}{\multicolumn{4}{|c|}{ Physical Properties }} & \multirow{2}{*}{\multicolumn{3}{|c|}{ Meta }} & & & \\
\hline & & & & & & & \multicolumn{2}{|c|}{ Chemical Properties } & \\
\hline \multicolumn{3}{|c|}{$\begin{array}{l}\text { Particle size } \\
\text { Distribution (\%) }\end{array}$} & $\begin{array}{l}\text { Textural } \\
\text { class }\end{array}$ & $\mathrm{pH}$ & $\begin{array}{l}\mathrm{OM} \\
(\%)\end{array}$ & $\begin{array}{l}\mathrm{OC} \\
(\%)\end{array}$ & $\begin{array}{l}\text { Total } \\
\text { N (\%) }\end{array}$ & $\begin{array}{l}\text { Av.P } \\
(\mathrm{ppm})\end{array}$ & $\begin{array}{c}\text { CEC } \\
\mathrm{Cmol} \mathrm{kg}^{-1}\end{array}$ \\
\hline Sand & Silt & Clay & clay & & & & & & \\
\hline 7 & 34 & 59 & & 7.66 & 3.59 & 2.08 & 0.17 & 20.46 & 46.68 \\
\hline
\end{tabular}

The organic matter content of the soil at Haramaya and Meta were 2.03\% and 3.59\%, respectively. According to Roy et al. (2006), the soils of both sites have high organic matter contents. Cation exchange capacity (CEC) is an important parameter of soil because it gives an indication of the type of clay mineral present in the soil and its capacity to retain nutrients against leaching. The CEC values of the soil were $\left(26.48 \mathrm{cmol} \mathrm{kg}^{-1}\right)$ and $(46.68 \mathrm{cmol}$ 
$\mathrm{kg}^{-1}$ soil) at Haramaya and Meta, respectively, which is high indicating its better capacity to retain the cations. Analysis of soil samples indicated low level of total N $(0.10 \%$ and $0.17 \%)$ at Haramaya and Meta, respectively, indicating that the nutrient is a limiting factor for optimum crop growth.

\subsection{Effects of Nitrogen Rate and Time of Application on Agronomic Traits of Bread Wheat Crop phenology \\ Days to 50\% heading}

Analysis of variance of the data revealed that the main effects of $\mathrm{N}$ rate and timing of $\mathrm{N}$ application significantly $(\mathrm{P}<0.01)$ influenced days to heading at Haramaya and Meta. However, the interaction effect of the two factors did not significantly influence days to $50 \%$ heading at both locations.

At Haramaya, the days to heading of plants was hastened under lower $\mathrm{N}$ rates compared to the higher $\mathrm{N}$ rates. Thus, increasing the rate of nitrogen from 0 to $46 \mathrm{~kg} \mathrm{~N}^{-1}$ prolonged days to heading by about $12.89 \%$; while, increasing the rate of nitrogen further from 0 to $69,92,115$ and $138 \mathrm{~kg} \mathrm{~N} \mathrm{ha}^{-1}$ prolonged the days to maturity by about $12.89 \%, 14 \%, 21.85 \%$ and $24.68 \%$, respectively, at Haramaya (Table 2). Thus, the most prolonged duration to heading was recorded under plants grown at the rate of $138 \mathrm{~kg} \mathrm{~N} \mathrm{ha}^{-1}$ whereas the shortest duration to heading was by plants grown at the control treatment.

Similarly, at Meta, the days to heading was significantly increased in response to increasing rate of nitrogen. While, there was consistency in the increase of this parameter with the increase in nitrogen application. The highest number of days to heading was required by plants grown at rate of $138 \mathrm{~kg} \mathrm{~N} \mathrm{ha}^{-1}$ (56.67 days) whereas the smallest number of days to heading was required by plants grown at nil rate of $\mathrm{N}$ application (Table 2). This might be because of the fact that high $\mathrm{N}$ rate promotes vigorous vegetative growth and development of the plants. Compared with days to heading obtained for the control treatment, the mean value of days to heading obtained at $115 \mathrm{~kg} \mathrm{~N}$ $\mathrm{ha}^{-1}$ was higher by about $12 \%$. Generally, the number of days to heading recorded over all the fertilized plots was significantly higher than the unfertilized plot (Table 2).

The delay in days to heading of wheat plants in response to the increased $\mathrm{N}$ rate $\left(115 \mathrm{~kg} \mathrm{ha}^{-1}\right)$ might be as a result of high $\mathrm{N}$ rate application that promoted vigorous vegetative growth and development of the plants possibly due to the availability of sufficient nutrient in the soil for plant uptake. This result is in line with the findings of Getachew (2004) who reported that the heading was significantly delayed at the highest $\mathrm{N}$ fertilizer rate compared to the lowest rate on wheat and barley crops, respectively. In contrast, to the results of the present study, Sewnet (2005) reported early flowering with an increase in the rate of $\mathrm{N}$ application in rice and in agreement with the results of this study, he also reported that sufficient nitrogen resulted in rapid growth and heading. Too little $\mathrm{N}$ resulted in slow growth rate and delayed heading and growth, whereas excessive $\mathrm{N}$ kept vegetative growth active and finally resulted in delayed heading and flowering.

Table 2. Days to $50 \%$ heading, biomass yield and grain yield of bread wheat as influenced by main effects of $\mathrm{N}$ rate and time of $\mathrm{N}$ application at Haramaya and Meta, eastern Ethiopia

\begin{tabular}{|c|c|c|c|c|c|c|}
\hline \multirow{2}{*}{$\begin{array}{c}\text { Treatments } \\
\text { N rate }\left(\mathrm{kg} \mathrm{ha}^{-1}\right)\end{array}$} & \multicolumn{3}{|c|}{ Haramaya } & \multicolumn{3}{|c|}{ Meta } \\
\hline & DTH & $\begin{array}{c}\text { BY } \\
\left(\mathrm{kg} \mathrm{ha}^{-1}\right)\end{array}$ & $\begin{array}{c}\mathrm{GY} \\
\left(\mathrm{kg} \mathrm{ha}^{-1}\right)\end{array}$ & DTH & $\begin{array}{c}\text { BY } \\
\left(\mathrm{kg} \mathrm{ha}^{-1}\right) \\
\end{array}$ & $\begin{array}{c}\mathrm{GY} \\
\left(\mathrm{kg} \mathrm{ha}^{-1}\right)\end{array}$ \\
\hline $\mathbf{0}$ & $53.00^{\mathrm{d}}$ & 6832 & $2680^{\mathrm{d}}$ & $50.00^{\mathrm{de}}$ & $6487^{c}$ & $2564^{\mathrm{d}}$ \\
\hline 46 & $59.83^{\mathrm{c}}$ & 18283 & $6253^{\mathrm{bc}}$ & $52.67^{\mathrm{e}}$ & $13968^{b}$ & $5501^{\mathrm{c}}$ \\
\hline 69 & $59.83^{\mathrm{b}}$ & 19183 & $6220^{b c}$ & $53.58^{d}$ & $14544^{\mathrm{ab}}$ & $5799^{b c}$ \\
\hline 92 & $60.42^{\mathrm{b}}$ & 18283 & $6914^{\mathrm{b}}$ & $54.92^{\mathrm{c}}$ & $16079^{\mathrm{ab}}$ & $6100^{\mathrm{abc}}$ \\
\hline 115 & $64.58^{\mathrm{b}}$ & 22646 & $7663^{b}$ & $56.00^{\mathrm{b}}$ & $16959^{a}$ & $6435^{\mathrm{ab}}$ \\
\hline 138 & $66.08^{\mathrm{a}}$ & 22125 & $8161^{\mathrm{a}}$ & $56.67^{\mathrm{a}}$ & $16923^{\mathrm{a}}$ & $6858^{\mathrm{a}}$ \\
\hline CD (0.05) & 0.86 & NS & 1256.30 & 0.56 & 1940.70 & 634.40 \\
\hline \multicolumn{7}{|c|}{$\mathrm{N}$ application time } \\
\hline$T_{1}$ & $63.00^{\mathrm{a}}$ & 20492 & 7138 & $55.12^{\mathrm{a}}$ & $16367^{\mathrm{ab}}$ & $6295^{\mathrm{ab}}$ \\
\hline $\mathbf{T}_{2}$ & $61.60^{\mathrm{b}}$ & 20095 & 7569 & $54.92^{\mathrm{a}}$ & $15241^{\mathrm{ab}}$ & $6115^{\mathrm{ab}}$ \\
\hline $\mathbf{T}_{3}$ & $61.73^{\mathrm{b}}$ & 19462 & 6890 & $53.78^{\mathrm{b}}$ & $14200^{b}$ & $5646^{\mathrm{b}}$ \\
\hline $\mathbf{T}_{4}$ & $62.27^{\mathrm{ab}}$ & 18322 & 6571 & $53.58^{\mathrm{b}}$ & $16970^{\mathrm{a}}$ & $6498^{a}$ \\
\hline CD (0.05) & 0.77 & NS & NS & 0.49 & 1735.80 & 567.40 \\
\hline CV $(\%)$ & 1.70 & 21.90 & 21.60 & 1.20 & 15.00 & 12.50 \\
\hline
\end{tabular}

Parameter means followed by the same letter within a column are not significantly different at $5 \%$ level of significance according to Tukey Tests; $\mathrm{DTH}=$ days to heading; $\mathrm{BY}=$ biomass yield; $\mathrm{GY}=$ grain yield; $\mathrm{CD}=\mathrm{critical}$ difference; $\mathrm{CV}=$ coefficient of variance; $\mathrm{NT}=$ time of $\mathrm{N}$ application; $\mathrm{NR}=\mathrm{N}$ rate $\left(\mathrm{kg} \mathrm{ha}^{-1}\right) ; \mathrm{T} 1=\mathrm{N}$ application of $1 / 2$ at planting and $1 / 2$ at mid-tillering; $\mathrm{T} 2=\mathrm{N}$ application of $1 / 2$ at mid-tillering and $1 / 2$ at anthesis; $\mathrm{T} 3=\mathrm{N}$ application of $1 / 3^{\text {rd }}$ at planting, $1 / 3^{\text {rd }}$ at mid-tillering and $1 / 3 \mathrm{rd}$ at anthesis; $\mathrm{T} 4=\mathrm{N}$ application of $1 / 4$ th at planting, $1 / 2$ at mid- 
tillering and $1 / 4$ th at anthesis.

\subsection{Days to $90 \%$ physiological maturity}

Days to $90 \%$ physiological maturity was highly significantly $(\mathrm{P}<0.01)$ affected by the main effects of timing of the $\mathrm{N}$ fertilizer application and significantly $(\mathrm{P}<0.05)$ by $\mathrm{N}$ fertilizer rate as well as by the interaction of the two factors at both sites.

At Haramaya, the maximum number of days to physiological maturity (110 days) was observed under plots received $138 \mathrm{~kg} \mathrm{~N} \mathrm{ha}^{-1}$ and $115 \mathrm{~kg} \mathrm{~N} \mathrm{ha}^{-1}$ in three splits of $1 / 4^{\text {th }}$ of the dose at planting, $1 / 2$ at mid-tillering and $1 / 4^{\text {th }}$ at anthesis and two splits of $1 / 2$ at mid-tillering and $1 / 2$ at anthesis, respectively (Table 3 ). The lowest days to physiological maturity (105.7 days) was recorded from $46 \mathrm{~kg} \mathrm{~N} \mathrm{ha}^{-1}$ with two split applications $(1 / 2$ at planting and $1 / 2$ at mid-tillering). Which, however, was not statistically different from the number of days to physiological maturity obtained under the nitrogen rate of 69 and $92 \mathrm{~kg} \mathrm{~N}$ ha $^{-1}$ applied in two splits $\left({ }^{1 / 2}\right.$ at planting and $1 / 2$ at midtillering) (Table 3). Thus, plants received $138 \mathrm{~kg} \mathrm{~N} \mathrm{ha}^{-1}$ applied in two equal splits of $1 / 2$ dose at planting and $1 / 2$ at mid-tillering and plants received $115 \mathrm{~kg} \mathrm{~N} \mathrm{ha}^{-1}$ in two equal splits of $1 / 2$ dose at mid-tillering and $1 / 2$ at anthesis reached heading about 4 days later than those plants grown under $1 / 4^{\text {th }}$ dose at planting, $1 / 2$ dose at mid-tillering and $1 / 4^{\text {th }}$ dose at anthesis of $46 \mathrm{~kg} \mathrm{~N} \mathrm{ha}^{-1}$.

At Meta, the maximum number of days to physiological maturity (107 days) was observed when $138 \mathrm{~kg} \mathrm{~N}$ $\mathrm{ha}^{-1}$ was applied in three splits of $1 / 4^{\text {th }}$ of the dose at planting, $1 / 2$ at mid-tillering and $1 / 4^{\text {th }}$ at anthesis, however, it was statistically on par with $115 \mathrm{~kg} \mathrm{~N} \mathrm{ha}^{-1}$ at two splits $1 / 2$ at mid-tillering and $1 / 2$ at anthesis (Table 3). The lowest days to physiological maturity (102.7 days) was recorded from $46 \mathrm{~kg} \mathrm{~N} \mathrm{ha}^{-1}$ with two split applications $\left({ }^{1} / 2\right.$ at planting and $1 / 2$ at mid-tillering). Increasing the rate of nitrogen application significantly prolonged the days to physiological maturity consistently of the bread wheat across all the application times. Over all times of nitrogen application, plants grown at the rate of $46 \mathrm{~kg} \mathrm{~N} \mathrm{ha}^{-1}$ at two splits $(1 / 2$ at planting and $1 / 2$ at mid-tillering) had significantly hastened days to heading (102.7 days) than those plants grown at the other four higher rates and times of nitrogen. Similarly, the number of days to heading recorded over all the treated plots was significantly higher than those unfertilized plot.

The delay in maturity of bread wheat plants in response to the increased $\mathrm{N}$ rate $\left(138 \mathrm{~kg} \mathrm{ha}^{-1}\right)$ and three split applications might be because of the fact that high $\mathrm{N}$ rate and three-time applications promoted vigorous vegetative growth and development of the plants possibly due to synchrony of the time of need of the plant for uptake of the nutrient and availability of the nutrient in the soil. The results, which obtained from this study is in conformity with the established fact that abundant supply of nitrogen delays physiological maturity by promoting vigorous vegetative growth of the plant (Osman and Mohamed, 1981).

Table 3. Mean days to $90 \%$ physiological maturity of bread wheat as affected by the interaction of rate and timing of nitrogen fertilizer application

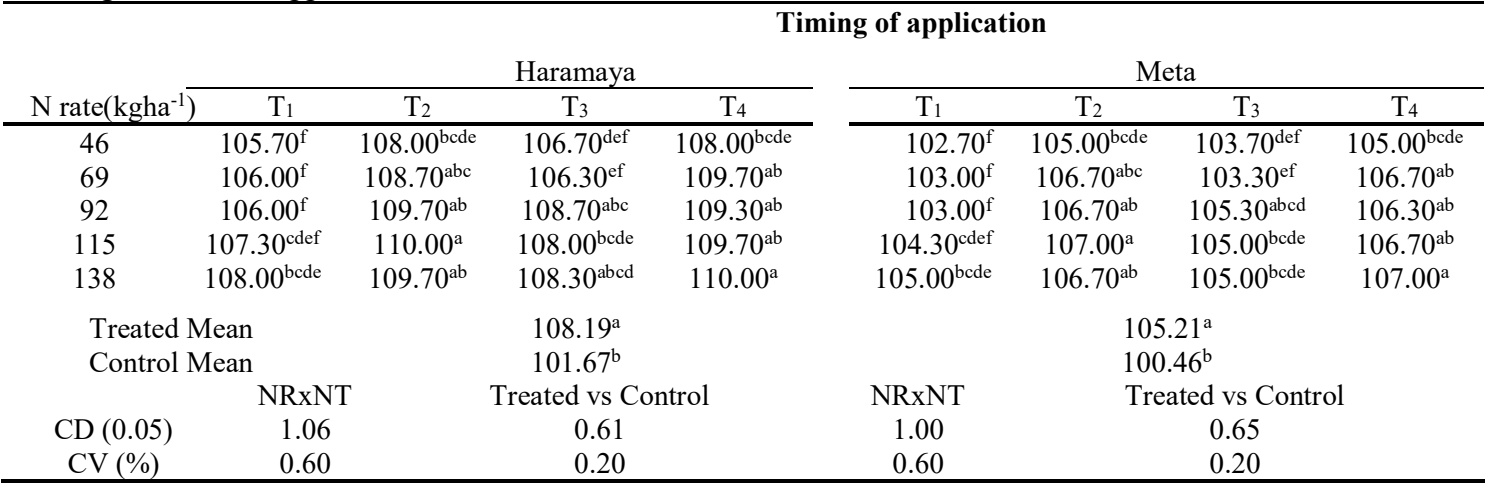

Parameter means followed by the same letter within a column and row are not significantly different at $5 \%$ level of significance according to Tukey test; $\mathrm{NT}=$ time of $\mathrm{N}$ application; $\mathrm{NR}=\mathrm{N}$ rate $\left(\mathrm{kg} \mathrm{ha}^{-1}\right) ; \mathrm{CD}=\mathrm{critical}$ difference; $\mathrm{CV}=$ coefficient of variance; $\mathrm{T} 1=\mathrm{N}$ application of $1 / 2$ at planting and $1 / 2$ at mid-tillering; $\mathrm{T} 2=\mathrm{N}$ application of $1 / 2$ at mid-tillering and $1 / 2$ at anthesis; $\mathrm{T} 3=\mathrm{N}$ application of $1 / 3^{\mathrm{rd}}$ at planting, $1 / 3^{\mathrm{rd}}$ at mid-tillering and $1 / 3 \mathrm{rd}$ at anthesis; $\mathrm{T} 4=\mathrm{N}$ application of $1 / 4$ th at planting, $1 / 2$ at mid-tillering and $1 / 4$ th at anthesis.

\subsection{Wheat growth parameters Plant height}

Plant height was highly significantly $(\mathrm{P}<0.01)$ affected by the main effects of timing of the $\mathrm{N}$ fertilizer application and $\mathrm{N}$ fertilizer rate as well as by the interaction of the two factors at Haramaya. At Meta, however, plant height was significantly $(\mathrm{P}<0.01)$ influenced by the main effects of rate and time of nitrogen application but not, by the interaction effect of the two factors (Appendix Table 3). 
For Haramaya, increasing the rate of nitrogen from nil up to the highest level led to significant increases in plant height across the two-time and the three-time split $\mathrm{N}$ applications. However, plants treated with the half dose of $\mathrm{N}$ at mid-tillering and the other half-dose $\mathrm{N}$ at the anthesis grew tallest in response to the application of $138 \mathrm{~kg}$ $\mathrm{N}$ ha ${ }^{-1}$. However, plants treated with all other split $\mathrm{N}$ applications attained their highest heights already at the application of $115 \mathrm{~kg} \mathrm{~N} \mathrm{ha}^{-1}$. For all split $\mathrm{N}$ application treatments except the treatment of half $\mathrm{N}$ dose at mid tillering and the other half $\mathrm{N}$ dose at anthesis, the shortest plants were attained at the rates of 46 and $69 \mathrm{~kg} \mathrm{~N} \mathrm{ha}^{-1}$. However, for the latter, the shortest plants were attained at $115 \mathrm{~kg} \mathrm{~N} \mathrm{ha}^{-1}$, but statistically there was no difference (Table 4).

The tallest plant height $(115.2 \mathrm{~cm})$ was observed when $138 \mathrm{~kg} \mathrm{~N} \mathrm{ha}^{-1}$ was applied in two splits of ${ }^{1 / 2}$ of the dose at mid-tillering and $1 / 2$ at anthesis. However, it was statistically at par with the plant height recorded at 115 $\mathrm{kg} \mathrm{N} \mathrm{ha}^{-1}(115.1 \mathrm{~cm})$ and $138 \mathrm{~kg} \mathrm{~N} \mathrm{ha}^{-1},(114.8 \mathrm{~cm})$, respectively, in three split applications of $1 / 4^{\text {th }}$ at planting, $1 / 2$ at mid-tillering and $1 / 4^{\text {th }}$ at anthesis. On the other hand, among the treatment combinations the shortest plant height $(99.4 \mathrm{~cm})$ was recorded at $46 \mathrm{~kg} \mathrm{~N} \mathrm{ha}^{-1}$ in three time split applications $1 / 3^{\mathrm{rd}}$ at planting, $1 / 3^{\mathrm{rd}}$ at mid-tillering and $1 / 3^{\mathrm{rd}}$ at anthesis (Table 4). Therefore, plants received $138 \mathrm{~kg} \mathrm{~N}$ ha $^{-1}$ applied in two equal splits of $1 / 2$ dose at planting and $1 / 2$ dose at mid-tillering and plants that received $115 \mathrm{~kg} \mathrm{~N}^{-1}$ in three splits of $1 / 4^{\text {th }}$ at planting, $1 / 2$ dose at midtillering and $1 / 4^{\text {th }}$ dose at anthesis were $15.90 \%$ more taller than those grown under three time of split applications of $1 / 3^{\text {rd }}$ at planting, ${ }^{1} /{ }^{\text {rd }}$ at mid-tillering and $1 / 3^{\text {rd }}$ at anthesis of $46 \mathrm{~kg} \mathrm{~N} \mathrm{ha}^{-1}$. Plant height generally increased with an increase in the rate and frequency of $\mathrm{N}$ application and the shortest plants were recorded from unfertilized plot (Table 4).

Thus, the mean height of plants grown at the rates of $138 \mathrm{~kg} \mathrm{~N} \mathrm{ha}^{-1}$ applied $1 / 2$ dose at mid-tillering and the other $1 / 2$ dose at anthesis was significantly superior than the mean heights of plants treated with 46, 69, 92 and 115 $\mathrm{kg} \mathrm{N}^{-1}$ rate applied $1 / 2$ dose at planting and the other $1 / 2$ dose at mid-tillering by $15.78 \%, 12.94 \%, 8.27 \%$ and $7.06 \%$, respectively. This difference might be due to the fact that the application of $1 / 2$ dose of nitrogen at planting may not lead to efficient recovery of the nutrient by roots and enhanced plant growth. Mean values for nitrogen rates showed that plant height increased with each increment of nitrogen rates from the control to the highest rate $\left(138 \mathrm{~kg} \mathrm{~N} \mathrm{ha}^{-1}\right)$ but the two higher $\mathrm{N}$ rates $\left(115\right.$ and $\left.138 \mathrm{~kg} \mathrm{~N} \mathrm{ha}^{-1}\right)$ were statistically at par. The increased plant height at the highest level of nitrogen was probably due to the availability of more nutrients, which helped, in maximum vegetative growth of wheat. This result was in tune with Khan et al. (2000) who reported that increasing nitrogen rates increased the wheat plant height.

At Meta, the tallest plant height $(110.1 \mathrm{~cm})$ was observed when $138 \mathrm{~kg} \mathrm{~N} \mathrm{ha}^{-1}$ was applied. Whereas the shortest plant height $(80.18 \mathrm{~cm})$ was recorded from control treatments (Table 9). An increase of nitrogen rate from 0 to $46 \mathrm{~kg} \mathrm{~N} \mathrm{ha}^{-1}$ increased the plant height by about $24.35 \%$ and further increasing the rate of nitrogen from 0 to $69,92,115$ and $138 \mathrm{~kg} \mathrm{~N} \mathrm{ha}^{-1}$ markedly increased the height of the plants by about $24.59 \%, 24.47 \%, 28.71 \%$ and $37.32 \%$, respectively. In line with this result, Amsal et al. (2000) observed a positive and linear response to applied $\mathrm{N}$ fertilizer to plant height in the central highlands of Ethiopia. Several studies in Ethiopia also exhibited increment in plant height in response to each increment of fertilizer $\mathrm{N}$ doses e.g. (Tilahun et al., 1996).

Plant height $(\mathrm{cm}) \quad$ Timing of application $\quad$ Spike length $(\mathrm{cm})$

\begin{tabular}{|c|c|c|c|c|c|c|c|c|}
\hline $\mathrm{N}$ rate $\left(\mathrm{kg} \mathrm{ha}^{-1}\right)$ & 1) $\mathrm{T}_{1}$ & $\mathrm{~T}_{2}$ & $\mathrm{~T}_{3}$ & $\mathrm{~T}_{4}$ & $\mathrm{~T}_{1}$ & $\mathrm{~T}_{2}$ & $\mathrm{~T}_{3}$ & $\mathrm{~T}_{4}$ \\
\hline $\begin{array}{ll}46 & 1\end{array}$ & $101.10^{\mathrm{gh}}$ & $99.50^{\mathrm{h}}$ & $99.40^{\mathrm{h}}$ & $100.30^{\text {gh }}$ & $6.41^{\mathrm{h}}$ & $6.44^{\mathrm{h}}$ & $6.77^{\mathrm{gh}}$ & $6.73^{\mathrm{gh}}$ \\
\hline 69 & $102.20^{\mathrm{fgh}}$ & $102.00^{\mathrm{fgh}}$ & $100.10^{\mathrm{gh}}$ & $103.00^{\mathrm{efg}}$ & $6.79^{\mathrm{gh}}$ & $7.04^{\mathrm{gh}}$ & $7.04^{\mathrm{g}}$ & $7.23^{\mathrm{fg}}$ \\
\hline 92 & $105.00^{\text {def }}$ & $106.40^{\text {cde }}$ & $106.40^{\text {cde }}$ & $106.70^{\mathrm{cd}}$ & $7.66^{\mathrm{f}}$ & $7.65^{f}$ & $8.62^{\text {cde }}$ & $8.50^{\mathrm{de}}$ \\
\hline 115 & $112.50^{\mathrm{ab}}$ & $107.60^{\mathrm{cd}}$ & $109.40^{\mathrm{bc}}$ & $115.10^{\mathrm{a}}$ & $8.45^{\mathrm{e}}$ & $9.26^{\mathrm{ab}}$ & $8.84^{\text {bcde }}$ & $9.07^{\mathrm{abcd}}$ \\
\hline 138 & $111.20^{\mathrm{b}}$ & $115.20^{\mathrm{a}}$ & $112.70^{\mathrm{ab}}$ & $114.80^{\mathrm{a}}$ & $9.12^{\mathrm{abc}}$ & $9.40^{\mathrm{ab}}$ & $9.16^{\mathrm{abc}}$ & $9.48^{\mathrm{a}}$ \\
\hline \multicolumn{3}{|c|}{ Treated Mean } & \multicolumn{2}{|l|}{$106.58^{\mathrm{a}}$} & \multicolumn{4}{|c|}{$7.99^{\mathrm{a}}$} \\
\hline \multicolumn{3}{|c|}{ Control Mean } & \multicolumn{2}{|c|}{$86.83^{\mathrm{b}}$} & \multicolumn{4}{|c|}{$5.82^{b}$} \\
\hline \multirow{2}{*}{\multicolumn{2}{|c|}{$\mathrm{CD}(0.05)$}} & NRxNT & \multicolumn{2}{|c|}{ Treated vs Control } & \multicolumn{2}{|c|}{ NRxNT } & \multicolumn{2}{|c|}{ Treated vs Control } \\
\hline & & 1.82 & \multicolumn{2}{|c|}{2.57} & \multicolumn{2}{|c|}{0.31} & \multicolumn{2}{|c|}{0.78} \\
\hline $\mathrm{CV}(\%)$ & & 1.00 & \multicolumn{2}{|c|}{0.80} & \multicolumn{2}{|c|}{2.30} & \multicolumn{2}{|c|}{3.20} \\
\hline
\end{tabular}

Table 4. Plant height and spike length of bread wheat as influenced by the interaction of $\mathrm{N}$ rate and time of $\mathrm{N}$ application at Haramaya

Parameter means followed by the same letter within a column and row are not significantly different at $5 \%$ level of significance according to Tukey Tests; $C D=$ critical difference; $C V=$ coefficient of variance; $N T=$ time of $\mathrm{N}$ application; $\mathrm{T} 1=\mathrm{N}$ application of $1 / 2$ at planting and $1 / 2$ at mid-tillering; $\mathrm{T} 2=\mathrm{N}$ application of $1 / 2$ at mid-tillering and $1 / 2$ at anthesis; $\mathrm{T} 3=\mathrm{N}$ application of $1 / 3^{\text {rd }}$ at planting, $1 / 3^{\text {rd }}$ at mid-tillering and $1 / 3$ rd at anthesis; $\mathrm{T} 4=\mathrm{N}$ application of $1 / 4$ th at planting, $1 / 2$ at mid-tillering and 1/4th at anthesis.

\section{Lodging percentage}

The degree of lodging was assessed just before the time of harvest by visual observation based on the scales of 1- 
5, where $1\left(0-15^{0}\right)$ indicates no lodging, $2\left(15-30^{\circ}\right)$ indicates $25 \%$ lodging, $3\left(30-45^{\circ}\right)$ indicates $50 \%$ lodging, 4 $\left(45-60^{\circ}\right)$ indicates $75 \%$ lodging and $5\left(60-90^{\circ}\right)$ indicates $100 \%$ lodging (Donald, 2004). However, none of the plots indicated lodging of plants and hence no data were recorded and reported for this parameter at both sites.

\section{Spike length}

Spike length is one of the growth parameters of bread wheat that contributes to grain yield. Crops with higher spike length could have higher grain yield. Spike length was highly significantly $(\mathrm{P}<0.01)$ affected by the main effects of timing of the $\mathrm{N}$ fertilizer application and $\mathrm{N}$ fertilizer rate as well as by the interaction of the two factors at Haramaya. Similarly, at Meta, the main effects of $\mathrm{N}$ rate and timing of $\mathrm{N}$ application significantly $(\mathrm{P}<0.01)$ influenced spike length while the interaction effect of the two factors not .

At Haramaya, spike length was significantly increased in response to increasing the rate of nitrogen across the application times. The maximum spike length $(9.48 \mathrm{~cm})$ was recorded in response to nitrogen applied at the rate of $138 \mathrm{~kg} \mathrm{~N} \mathrm{ha}^{-1}$ with three time split application of $1 / 4^{\text {th }}$ at planting, $1 / 2$ at mid-tillering and the other $1 / 4^{\text {th }}$ at anthesis. While, the lowest spike length of $(6.41 \mathrm{~cm})$ was obtained from plots treated with $46 \mathrm{~kg} \mathrm{~N}^{-1}$ nitrogen in two split applications $1 / 2$ at planting and $1 / 2$ at mid-tillering. The spike length of unfertilized treatment was low as compared to treated plots (Table 4). The enhancement of spike length development of plants that received nitrogen at higher rates $\left(138 \mathrm{~kg} \mathrm{~N} \mathrm{ha}^{-1}\right)$ and well-spaced in three time $\mathrm{N}$ applications as the plant demand and $\mathrm{N}$ supply in the soil may have been synchronized for high uptake by roots. This result is in agreement with that of Gooding and Davis (1997) who reported that spike length increased significantly with increased application of $\mathrm{N}$.

At Meta, as the nitrogen rate increased from 0 to $138 \mathrm{~kg} \mathrm{ha}^{-1}$, spike length was increased by $32.33 \%$. However, there was no significant difference in spike length attained at 92 and $115 \mathrm{~kg} \mathrm{~N} \mathrm{ha}^{-1}$ (Table 9). Higher spike length at the higher doses of nitrogen might be due to the availability of nitrogen in significant quantity to keep the plant healthy which ultimately resulted in proportional increase in spike length corresponding to the amount of fertilizer used when compared to the non-fertilized wheat crops (Ejaz et al., 2002).

\subsection{Yield components and yield \\ Total number of tillers per 0.5 m length}

Crops with higher total number of tillers could have higher grain yield, straw yield and biomass yield. The total number of tillers per $0.5 \mathrm{~m}$ was highly significantly $(\mathrm{P}<0.01)$ affected by the main effect of $\mathrm{N}$ application, but not by the time of $\mathrm{N}$ applications as well as by the interaction effect of the two factors at both sites.

At Haramaya, the total number of tillers was significantly increased in response to increasing rate of nitrogen. However, there was less consistency in the increase of this parameter with the increase in nitrogen application. The highest total number of tillers per $0.5 \mathrm{~m}$ length $(22.19 \%)$ was recorded in response to nitrogen applied at the rate of $115 \mathrm{~kg} \mathrm{~N} \mathrm{ha}^{-1}$ while the lowest total number of tillers per $0.5 \mathrm{~m}(18.52 \%)$ was obtained from plots treated with $69 \mathrm{~kg} \mathrm{~N} \mathrm{ha}^{-1}$. However, this value was statistically in parity with the total number of tillers per $0.5 \mathrm{~m}(19.70 \%$, $21.12 \%$ and $22.19 \%$ ) obtained under the nitrogen rate of 46,92 and $115 \mathrm{~kg} \mathrm{~N} \mathrm{ha}^{-1}$, respectively. Compared with total number of tillers per $0.5 \mathrm{~m} \mathrm{(50.60)} \mathrm{obtained} \mathrm{for} \mathrm{the} \mathrm{control} \mathrm{treatment,} \mathrm{the} \mathrm{mean} \mathrm{total} \mathrm{and} \mathrm{productive} \mathrm{number}$ of tillers per $0.5 \mathrm{~m}$ obtained at $115 \mathrm{~kg} \mathrm{~N} \mathrm{ha}^{-1}$ was higher by about $22.19 \%$.

At Meta, the total number of tillers per $0.5 \mathrm{~m}$ was significantly increased in response to increasing rate of nitrogen. The highest number of tillers per $0.5 \mathrm{~m}$ (60.01) was recorded in response to nitrogen applied at the rate of $138 \mathrm{~kg} \mathrm{~N} \mathrm{ha}^{-1}$ and it was statistically in parity with the total number of tillers per $0.5 \mathrm{~m}$ obtained under the nitrogen rate of 46, 69, 92 and $115 \mathrm{~kg} \mathrm{~N} \mathrm{ha}^{-1}$, respectively (Table 7). The lowest total number of tillers per $0.5 \mathrm{~m}$ (53.94) was obtained from plots treated with $46 \mathrm{~kg} \mathrm{~N} \mathrm{ha}^{-1}$. Compared with total number of tillers per $0.5 \mathrm{~m}$ obtained for the control treatment, the total number of tillers per $0.5 \mathrm{~m}$ obtained at $138 \mathrm{~kg} \mathrm{~N} \mathrm{ha}^{-1}$ was higher by about $68.05 \%$. In accordance with $\mathrm{N}$ fertilizer rate, the total number of tillers per $0.5 \mathrm{~m}$ row length increased linearly.

The results of total number of tillers per $0.5 \mathrm{~m}$ length obtained from this is in line with that of Ayoub et al. (1994) and Tilahun et al. (1996) where they observed increasing spike density at harvest as level of applied N fertilizer increased and they attributed such increase to the increment of number of productive tillers per unit area. Corroborating with the results of this study, Botella et al. (1993) reported stimulation of tillering with high application of nitrogen might be due to its positive effect on cytokinin synthesis.

\section{Number of effective tillers per meter square}

The number of effective tillers per meter square was significantly $(\mathrm{P}<0.05)$ affected by $\mathrm{N}$ time of applications but not significantly by $\mathrm{N}$ fertilizer rate as well as interaction effect of the two factors at Haramaya (Appendix Table 5), on the other hand, the number of effective tillers per meter square did not respond significantly affected by applied $\mathrm{N}$ rate, $\mathrm{N}$ time and the interaction between $\mathrm{N}$ rates and $\mathrm{N}$ time at.

\section{Number of effective tillers per plant}

Number of effective tillers per plant was highly significantly $(\mathrm{P}<0.01)$ affected by the main effects of rate and timing of $\mathrm{N}$ fertilizer application and significantly $(\mathrm{P}<0.05)$ influenced by the interaction effect at Haramaya, whereas, highly significantly $(\mathrm{P}<0.01)$ effect was observed by the main effects of rate and timing of $\mathrm{N}$ fertilizer application and interaction effect at Meta . 
At Haramaya, most vigorous increase in number of effective tillers was attained at the split application of $1 / 4^{\text {th }} \mathrm{N}$ at planting, $1 / 2$ at mid-tillering, and the other $1 / 4^{\text {th }}$ at anthesis, the maximum was attained at $138 \mathrm{~kg} \mathrm{~N} \mathrm{ha}^{-1}$. However, it was statistically at par with the number of effective tillers per plant recorded at 92 and $115 \mathrm{~kg} \mathrm{~N} \mathrm{ha}^{-1}$, in three split applications of $1 / 4^{\text {th }} \mathrm{N}$ at planting, $1 / 2$ at mid-tillering, and the other $1 / 4^{\text {th }}$ at anthesis, respectively and also it did not significant difference between 115 and $138 \mathrm{~kg} \mathrm{~N} \mathrm{ha}^{-1}$, in the two split applications $1 / 2$ dose at planting and $1 / 2$ at mi-tillering and $1 / 2$ at mid-tillering and $1 / 2$ at anthesis, respectively. Whereas, the least response in the production of effective tillers was observed for the split $\mathrm{N}$ application of $1 / 3^{\text {rd }}$ at the three growth stages of the plant, which attained lower number of effective tillers even at the highest rate of $\mathrm{N}$ application compared to the other treatments at this rate of $\mathrm{N}$ supply.

Similarly, at Meta, the most vigorous and linear increases in effective tiller production was attained for split application of $1 / 4^{\text {th }} \mathrm{N}$ at planting, $1 / 2$ at mid-tillering, and the other $1 / 4^{\text {th }}$ at anthesis as well as for the split application of $1 / 2$ at planting and $1 / 2$ at mid-tillering. Among both doses of application, the optimum effective tillers were produced at the highest rate of $\mathrm{N}$ supply $\left(138 \mathrm{~kg} \mathrm{~N} \mathrm{ha}^{-1}\right)$. However, for the other two split $\mathrm{N}$ application treatments, the increase in effective tiller production was weak compared to the other treatments. Thus, for these two tretaments not optimal effective tiller numbers were attained even at the highest level of $\mathrm{N}$ rate. The increase in number of effective tillers with the increased $\mathrm{N}$ levels was possibly due to adequate availability of $\mathrm{N}$ which might have facilitated tillering or contributed to tiller maintenance when the rate changed from 46 to $138 \mathrm{~kg} \mathrm{~N} \mathrm{ha}^{-1}$ (Table 5).

The above result of both sites indicated the enhancement of effective tiller development of bread wheat plants that received nitrogen at higher rates but well-spaced in time as the plant demand and $\mathrm{N}$ supply in the soil may have been synchronized for high uptake by roots. The current result is in agreement with that of Genene (2003) who reported higher tillering and maximum survival percentage of tillers with increasing $\mathrm{N}$ application in bread wheat. Corroborating the results of this study, Botella et al. (1993) reported that stimulation of tillering with high application of nitrogen might be due to its positive effect on cytokinin synthesis. This indicated the application of higher dose of $\mathrm{N}$ was important for tiller formation and development.

Table 5. Number of effective tillers per plant of bread wheat as influenced by the interaction of $\mathrm{N}$ rate and time of $\mathrm{N}$ application at Harmaya and Meta, eastern Ethiopia

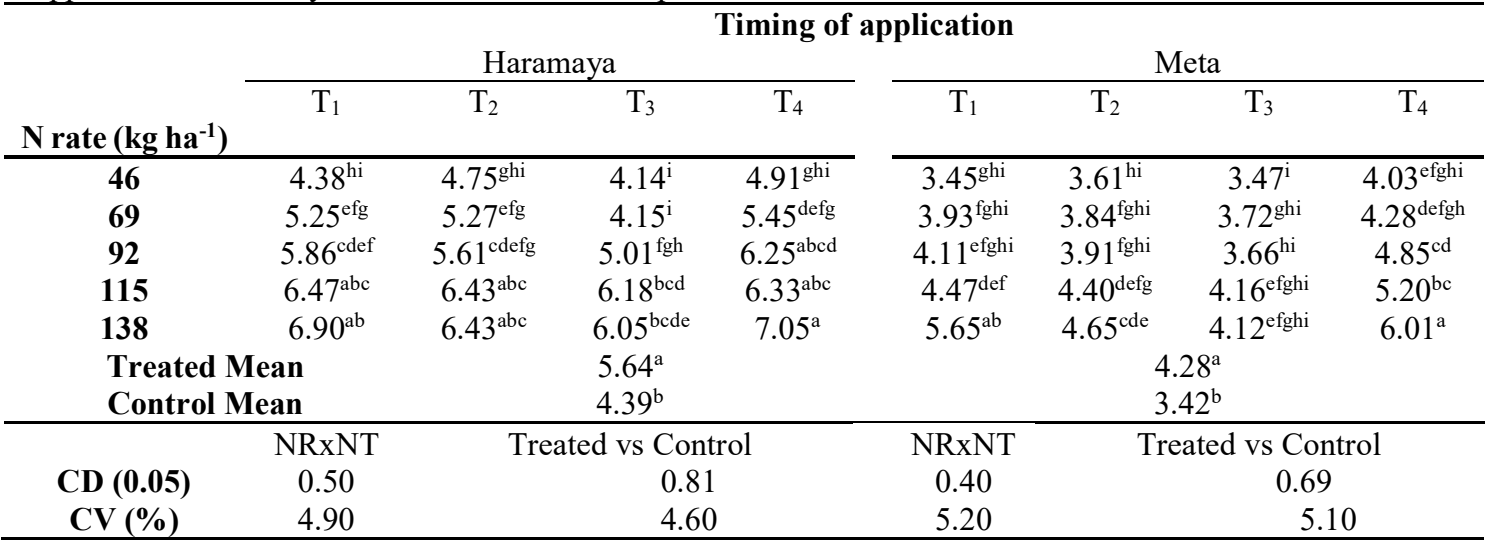

Parameter means followed by the same letter within a column and row are not significantly different at $5 \%$ level of significance according to Tukey Tests; $\mathrm{NT}=$ time of $\mathrm{N}$ application; $\mathrm{NR}=\mathrm{N}$ rate $\left(\mathrm{kg} \mathrm{ha}^{-1}\right) ; \mathrm{CD}=$ critical difference; $\mathrm{CV}=$ coefficient of variance; $\mathrm{T} 1=\mathrm{N}$ application of $1 / 2$ at planting and $1 / 2$ at mid-tillering; $\mathrm{T} 2=\mathrm{N}$ application of $1 / 2$ at mid-tillering and $1 / 2$ at anthesis; $\mathrm{T} 3=\mathrm{N}$ application of $1 / 3^{\text {rd }}$ at planting, $1 / 3^{\text {rd }}$ at mid-tillering and $1 / 3 \mathrm{rd}$ at anthesis; $\mathrm{T} 4=\mathrm{N}$ application of $1 / 4$ th at planting, $1 / 2$ at mid-tillering and $1 / 4$ th at anthesis.

\section{Number of kernels per spike}

The main effect of timing of nitrogen application did not significantly affect the number of kernels per spike. However, the main effect of rate of nitrogen and the interaction effect of rate and timing of nitrogen application highly significantly $(\mathrm{P}<0.01)$ affected this parameter at Haramaya (Appendix Table 5). Whereas, the main and the interaction effect of rate and timing of nitrogen application did not significantly affect this parameter at Meta (Appendix Table 4).

At Haramaya, the number of kernels per spike was significantly increased in response to increasing rate of nitrogen across the application times. However, there was less consistency in the increase of this parameter with the increase in frequency of application. The highest number of kernels per spike (66.3) was recorded in response to nitrogen applied at the rate of $138 \mathrm{~kg} \mathrm{~N} \mathrm{ha}^{-1}$ with three splits $\left(1 / 3^{\text {rd }}\right.$ at planting, $1 / 3^{\text {rd }}$ at mid-tillering and $1 / 3^{\text {rd }}$ at anthesis). While, the lowest number of kernels per spike (45.33) was obtained from plots treated with $46 \mathrm{~kg} \mathrm{~N} \mathrm{ha-}$ ${ }^{1}$ nitrogen in three split applications $\left(1 / 3^{\text {rd }}\right.$ dose at planting $+1 / 3^{\text {rd }}$ at mid-tillering and $1 / 3^{\text {rd }}$ at anthesis $)$. The number of kernels per spike for the highest $\mathrm{N}$ rate exceeded the lowest rate $\left(46 \mathrm{~kg} \mathrm{~N} \mathrm{ha}^{-1}\right)$ by $46.26 \%$ and $\left(0 \mathrm{~N} \mathrm{~kg} \mathrm{ha}^{-1}\right)$ by 


\section{$57.4 \%$ (Table 6)}

In line with this result, Ayoub et al. (1994) reported that nitrogen increased the number of grains per spike and that it is the best indicator of wheat response to nitrogen (138 kg N ha-1). Moreover, Hussins and Shah (2002) also reported that the number of kernels per spike increased with an increase in $\mathrm{N}$ rate.

Table 6. Mean number of kernels per spike of bread wheat as affected by main effects of $\mathrm{N}$ rates and timing of $\mathrm{N}$ application at Haramaya

\begin{tabular}{|c|c|c|c|c|}
\hline \multicolumn{5}{|c|}{ Timing of application } \\
\hline N Rate $\left(\mathrm{kg} \mathrm{ha}^{-1}\right)$ & $\mathrm{T}_{1}$ & $\mathrm{~T}_{2}$ & $\mathrm{~T}_{3}$ & $\mathrm{~T}_{4}$ \\
\hline 46 & $49.00^{\text {efgh }}$ & $47.00^{\text {fgh }}$ & $45.33^{\mathrm{h}}$ & $46.33^{\mathrm{gh}}$ \\
\hline 69 & $51.33^{\mathrm{ef}}$ & $49.67^{\mathrm{efgh}}$ & $50.00^{\text {efg }}$ & $50.67^{\mathrm{efg}}$ \\
\hline 92 & $51.00^{\mathrm{ef}}$ & $51.67^{\mathrm{e}}$ & $53.00^{\mathrm{e}}$ & $51.67^{\mathrm{e}}$ \\
\hline 115 & $61.00^{\mathrm{bcd}}$ & $59.33^{\mathrm{cd}}$ & $57.67^{d}$ & $61.00^{\mathrm{bcd}}$ \\
\hline 138 & $61.00^{\mathrm{bcd}}$ & $64.00^{\mathrm{ab}}$ & $66.30^{\mathrm{a}}$ & $62.67^{\mathrm{abc}}$ \\
\hline Treated Mean & \multirow{2}{*}{\multicolumn{4}{|c|}{$\begin{array}{l}54.48^{\mathrm{a}} \\
40.33^{\mathrm{b}} \\
\end{array}$}} \\
\hline Control Mean & & & & \\
\hline & \multicolumn{2}{|c|}{ NRxNT } & \multicolumn{2}{|c|}{ Treated vs Control } \\
\hline $\mathrm{CD}(0.05)$ & \multicolumn{2}{|c|}{2.41} & \multicolumn{2}{|c|}{3.95} \\
\hline $\mathrm{CV}(\%)$ & \multicolumn{2}{|c|}{2.70} & \multicolumn{2}{|c|}{2.40} \\
\hline
\end{tabular}

Parameter means followed by the same letter within a column and row are not significantly different at $5 \%$ level of significance according to Tukey Tests; $\mathrm{CD}=$ critical difference; $\mathrm{CV}=$ coefficient of variance; $\mathrm{NT}=$ time of $\mathrm{N}$ application; $\mathrm{NR}=\mathrm{N}$ rate $\left(\mathrm{kg} \mathrm{ha}^{-1}\right) ; \mathrm{T} 1=\mathrm{N}$ application of $1 / 2$ at planting and $1 / 2$ at mid-tillering; $\mathrm{T} 2=; \mathrm{N}$ application of $1 / 2$ at mid-tillering and $1 / 2$ at anthesis; T3 $=\mathrm{N}$ application of $1 / 3^{\text {rd }}$ at planting, $1 / 3^{\text {rd }}$ at mid-tillering and $1 / 3 \mathrm{rd}$ at anthesis; $\mathrm{T} 4=\mathrm{N}$ application of $1 / 4$ th at planting, $1 / 2$ at mid-tillering and $1 / 4$ th at anthesis.

\section{Aboveground dry biomass}

Analysis of variance indicated that the aboveground dry biomass did not respond significantly to the effects of $\mathrm{N}$ rate, $\mathrm{N}$ time of applications as well as interaction effect at Haramaya (Appendix Table 6). On the other hand, the main effects of $\mathrm{N}$ rate and timing of $\mathrm{N}$ application significantly $(\mathrm{P}<0.05)$ influenced aboveground dry biomass. However, the interaction effect of the two factors did not significantly influence this trait at Meta (Appendix Table 5).

At Meta, the highest aboveground dry biomass $\left(16959 \mathrm{~kg} \mathrm{ha}^{-1}\right)$ was produced at the rate of $115 \mathrm{~kg} \mathrm{~N} \mathrm{ha}^{-1}$ which, however, it was statistically at par with the aboveground dry biomass $\left(16923 \mathrm{~kg} \mathrm{ha}^{-1}\right)$ obtained under the $138 \mathrm{~kg} \mathrm{~N} \mathrm{ha}^{-1}$, while the lowest biomass $\left(6487 \mathrm{~kg} \mathrm{ha}^{-1}\right)$ was produced from unfertilized plot $\left(0 \mathrm{~kg} \mathrm{~N} \mathrm{ha}{ }^{-1}\right)(\mathrm{Table}$ $2)$. The result generally showed an increase in biomass production when $\mathrm{N}$ application increased from the lowest to the highest rate. Aboveground dry biomass was significantly increased with increase in the rate of nitrogen application. Increasing the rate of nitrogen from 0 to $138 \mathrm{~kg} \mathrm{~N} \mathrm{ha}^{-1}$ significantly increased aboveground dry biomass by about $160.87 \%$.

The increase in aboveground dry biomass with increased $\mathrm{N}$ rate might be attributed to the enhanced availability of $\mathrm{N}$ for vegetative growth of the plants. In conformity with this result, Ali et al. (2005) and Iqtidar et al. (2006) reported the highest aboveground dry biomass in the highest application rates of 210 and $200 \mathrm{~kg} \mathrm{~N} \mathrm{ha}^{-1}$ were linearly increased with $\mathrm{N}$ levels.

\section{Grain yield}

At Haramaya, the main effect of $\mathrm{N}$ rate had a highly significant $(\mathrm{P}<0.01)$ influence on grain yield; but the main effect of $\mathrm{N}$ application time as well as its interaction with $\mathrm{N}$ application rate did not influence this. Similarly, at Meta, the main effects of $\mathrm{N}$ rate and timing of $\mathrm{N}$ application significantly $(\mathrm{P}<0.05)$ influenced grain yield. However, the interaction effect of the two factors did not affect this parameter (Appendix Table 5).

At Haramaya, increasing the rate of the fertilizer from nil to $46 \mathrm{~kg} \mathrm{~N} \mathrm{ha}^{-1}$ and beyond increased grain yield. The response of the increase in grain yield to $\mathrm{N}$ application at this location was not linear, with the grain yield at most of the $\mathrm{N}$ rates being in statistical parity. Thus, highest grain yield was obtained in response to the application of $138 \mathrm{~kg} \mathrm{~N} \mathrm{ha}^{-1}$, indicating the need to increase the nitrogen rate to set optimum yield (Table 2). In general, increasing the rate of $\mathrm{N}$ from nil to $46,69,92,115$ and $138 \mathrm{~kg} \mathrm{~N}^{-1}$ increased grain yield by $133,132,158,186$ and $205 \%$, respectively.

Similarly, at Meta, increasing the rate of $\mathrm{N}$ supply from nil to $46,69,92,115$ and $138 \mathrm{~kg} \mathrm{~N}^{-1}$ led to significant increases in the grain yield of the crop by about $114.5,126,138,151$ and $167 \%$, respectively. However, at this site, the optimum grain yield was attained already at $138 \mathrm{~kg} \mathrm{~N} \mathrm{ha}^{-1}$, indicating that application of $\mathrm{N}$ beyond this level might contribute to the yield of the crop. Comparing the response of the crop in grain yield at the two locations, it appears that at both sites, the $\mathrm{N}$ fertilizer threshold for high wheat grain yield is high. The results also indicated that both locations have higher potential for attaining high yield at all levels of the applied $\mathrm{N}$ fertilizer (Table 2).

Generally, wheat grain yield consistently increased as the rate of applied $\mathrm{N}$ increased to the highest level of 
$\mathrm{N}$ and the grain yields recorded due to each successive rate of $\mathrm{N}$ were significantly different from each other. The results obtained from this study in lined with the research findings of many previous works (e.g. Hailu, (1991); Tanner et al., (1992); Minale et al., (2005); Getachew, (2004) who reported significant increases in grain yields of bread wheat with increasing application levels of $\mathrm{N}$ fertilizer.

Several studies reported positive and linear responses of grain yield to incremental rates of N (e.g. Asnakew et al., 1991; Tilahun et al., 1996; Amsal et al., 2000). Quadratic response was also observed in the Vertisols of central Ethiopia (Amsal et al., 2000). Tilahun et al. (1996) reported a range of 19 to 49\% yield advancement for two rates (120 over $60 \mathrm{~kg} \mathrm{~N} \mathrm{ha}^{-1}$ ) depending on the inherent $\mathrm{N}$ status of the soil, the amount and distribution of rainfall during the growing season of the respective locations. The $\mathrm{N}$ fertilizer study also showed a strong linear response of grain yield with a range of 2129 to $4152 \mathrm{~kg} \mathrm{ha}^{-1}$ (Taye et al., 2002).

\section{Harvest index}

Harvest index was computed as the ratio of grain yield to the total above ground dry biomass yield. Analysis of variance indicated that the harvest index did not respond significantly to the effects of $\mathrm{N}$ rate, $\mathrm{N}$ time of applications as well as interaction effect of those two factors at both sites (Appendix Table 5). Harvest index tended to decrease with increased application of nitrogen. However, there was no consistent trend of increase or decrease in harvest index with the doses of nitrogen application. For the rates of $0 \mathrm{~kg} \mathrm{~N} \mathrm{ha}^{-1}$ and $69 \mathrm{~kg} \mathrm{~N} \mathrm{ha}^{-1}$, slightly the maximum harvest index (0.41) and the minimum harvest index (0.33), respectively, were recorded at Haramaya (Table 7). On the other hand, the rates of $138 \mathrm{~kg} \mathrm{~N} \mathrm{ha}^{-1}$ and $115 \mathrm{~kg} \mathrm{~N} \mathrm{ha}^{-1}$, the maximum harvest index $(0.41)$ and the minimum harvest index (0.38), respectively, were scored at Meta (Table 7). In line with these results, Abdo (2009) reported highest harvest index from treatments with the lowest rate of nitrogen application. Most of the indices obtained due to different combinations of timing and $\mathrm{N}$ rates ranged from 0.33 to 0.41 (Table 6) and it is in agreement with that of Mengel and Kirkby (1996), who reported harvest indices of modern wheat cultivars that range from 0.35 to 0.40 .

Table 7. Harvest index, hectolitre weight, total number of effective tillers per $0.5 \mathrm{~m}$ and number of effective tillers per meter square of bread wheat as influenced by main effect of $\mathrm{N}$ rate and time of $\mathrm{N}$ application at Haramaya and Meta, eastern Ethiopia

\begin{tabular}{|c|c|c|c|c|c|c|c|c|}
\hline \multirow{2}{*}{$\begin{array}{c}\text { Treatments } \\
\begin{array}{c}\mathrm{N} \text { rate }(\mathrm{kg} \\
\left.\mathrm{ha}^{-1}\right)\end{array}\end{array}$} & \multicolumn{4}{|c|}{ Haramaya } & \multicolumn{4}{|c|}{ Meta } \\
\hline & $\mathrm{HI}$ & $\begin{array}{c}\mathrm{HLW} \\
\left(\mathrm{kg} \mathrm{hL}^{-1}\right)\end{array}$ & TNT & NETPMS & $\mathrm{HI}$ & HLW & TNT & NETPMS \\
\hline 0 & 0.41 & 79.00 & $50.60^{c}$ & 253.00 & 0.40 & 78.13 & $35.71^{b}$ & $178.60^{\mathrm{b}}$ \\
\hline 46 & 0.35 & 77.94 & $60.57^{\mathrm{a}}$ & 302.80 & 0.40 & 78.08 & $53.94^{\mathrm{a}}$ & $269.90^{\mathrm{a}}$ \\
\hline 69 & 0.33 & 78.88 & $59.97^{\mathrm{a}}$ & 299.80 & 0.40 & 78.57 & $55.01^{\mathrm{a}}$ & $275.10^{\mathrm{a}}$ \\
\hline 92 & 0.38 & 78.34 & $61.33^{\mathrm{a}}$ & 306.70 & 0.38 & 78.71 & $57.43^{\mathrm{a}}$ & $287.20^{\mathrm{a}}$ \\
\hline 115 & 0.34 & 78.12 & $61.83^{\mathrm{a}}$ & 309.20 & 0.38 & 78.32 & $57.71^{\mathrm{a}}$ & $288.60^{\mathrm{a}}$ \\
\hline 138 & 0.39 & 77.81 & $60.65^{\mathrm{b}}$ & 303.20 & 0.41 & 78.32 & $60.01^{\mathrm{a}}$ & $300.00^{\mathrm{a}}$ \\
\hline $\mathrm{CD}(0.05)$ & NS & NS & 5.40 & NS & NS & NS & 8.20 & 40.80 \\
\hline \multicolumn{9}{|c|}{$\begin{array}{c}\mathrm{N} \text { application } \\
\text { Time }\end{array}$} \\
\hline $\mathrm{T}_{1}$ & 0.35 & 78.16 & 63.07 & 317.80 & 0.39 & $77.74^{\mathrm{c}}$ & 57.39 & 287.00 \\
\hline $\mathrm{T}_{2}$ & 0.38 & 78.45 & 58.99 & 297.40 & 0.40 & $79.05^{\mathrm{a}}$ & 55.96 & 279.00 \\
\hline $\mathrm{T}_{3}$ & 0.35 & 78.42 & 59.00 & 297.50 & 0.40 & $78.74^{\mathrm{ab}}$ & 51.95 & 259.70 \\
\hline $\mathrm{T}_{4}$ & 0.36 & 77.98 & 60.46 & 304.70 & 0.39 & $78.03^{b c}$ & 57.97 & 289.80 \\
\hline $\mathrm{CD}(0.05)$ & NS & NS & NS & NS & NS & 1.67 & NS & NS \\
\hline CV $(\%)$ & 19.00 & 1.90 & 6.90 & 6.90 & 7.70 & 1.20 & 11.20 & 11.20 \\
\hline
\end{tabular}

Parameter means followed by the same letter within a column are not significantly different at $5 \%$ level of significance according to Tukey Tests; $\mathrm{CD}=$ critical difference; $\mathrm{CV}=$ coefficient of variance; $\mathrm{HI}=$ harvest index; HLW= hectolitre weight; TNT = total number of tillers per 0.5 meter length; NETPMS = number of effective tillers per meter square; $\mathrm{NT}=$ time of $\mathrm{N}$ application; $\mathrm{NR}=\mathrm{N}$ rate $\left(\mathrm{kg} \mathrm{ha}^{-1}\right) ; \mathrm{T} 1=\mathrm{N}$ application of $1 / 2$ at planting and $1 / 2$ at mid-tillering; $\mathrm{T} 2=\mathrm{N}$ application of $1 / 2$ at mid-tillering and $1 / 2$ at anthesis; $\mathrm{T} 3=\mathrm{N}$ application of $1 / 3^{\text {rd }}$ at planting, $1 / 3^{\text {rd }}$ at mid-tillering and $1 / 3$ rd at anthesis; $T 4=\mathrm{N}$ application of $1 / 4$ th at planting, $1 / 2$ at mid-tillering and $1 / 4$ th at anthesis.

\section{SUMMARY AND CONCLUSION}

Low available soil nutrient status and reduced plant use efficiency are some of the major constraints limiting wheat yield and quality in growing areas of Ethiopia. Ensuring a well-balanced supply of $\mathrm{N}$ to the bread wheat may result in higher grain yield and increased grain protein accumulation. Therefore, experiment was conducted with the objectives of assessing the effects of rates and time of application of nitrogen fertilizer on the growth, yield components, yield and grain protein of bread wheat; and to determine the effects of rates and time of nitrogen fertilizer application on $\mathrm{N}$ use efficiency of bread wheat. 
The experiment was laid out in a randomized complete block design in a factorial arrangement with three replications. The treatments consisted of factorial combinations of six levels of nitrogen $(0,46,69,92,115$ and $\left.138 \mathrm{~kg} \mathrm{~N} \mathrm{ha}{ }^{-1}\right)$ and four split application times $(1 / 2$ at planting $+1 / 2$ at mid-tillering, $1 / 2$ at mid-tillering $+1 / 2$ at anthesis, $1 / 3^{\text {rd }}$ at planting $+1 / 3^{\text {rd }}$ at mid-tillering $+1 / 3^{\text {rd }}$ at anthesis and $1 / 4^{\text {th }}$ at planting $+1 / 2$ at mid-tillering $+1 / 4^{\text {th }}$ at anthesis).

The main effect due to rate of $\mathrm{N}$ application significantly influenced days to heading, grain yield, grain protein concentration, concentration of $\mathrm{N}$ in shoot, grain nitrogen content and straw nitrogen content, with $\mathrm{N}$ rate of 138 $\mathrm{kg} \mathrm{ha}^{-1}$ producing the highest days to heading, grain yield, grain protein concentration, concentration of $\mathrm{N}$ in shoot, grain nitrogen content and straw nitrogen content at both sites.

The grain yield exhibited significant differences in response to $\mathrm{N}$ rate. The highest and lowest mean grain yield $\left(8161 \mathrm{~kg} \mathrm{ha}^{-1}\right)$ and $\left(2680 \mathrm{~kg} \mathrm{ha}^{-1}\right)$ were obtained from the application of the highest $\mathrm{N}$ rate $\left(138 \mathrm{~kg} \mathrm{ha}^{-1}\right)$ and from the control treatment, respectively, at Haramaya. Whereas the highest mean grain yield $\left(6858 \mathrm{~kg} \mathrm{ha}^{-1}\right) \mathrm{was}^{-1}$ obtained from the highest $\mathrm{N}$ application rate $\left(138 \mathrm{~kg} \mathrm{ha}^{-1}\right)$, with an increment of $4294 \mathrm{~kg} \mathrm{ha}^{-1}+167.47 \%$ compared to control $\left(2564 \mathrm{~kg} \mathrm{ha}^{-1}\right)$ at Meta. Generally, wheat grain yield consistently increased as the rate of applied $\mathrm{N}$ increased to the highest level of $\mathrm{N}$.

The main effect of time of $\mathrm{N}$ application had significant effect on days to heading, grain protein concentration, grain nitrogen concentration, straw nitrogen concentration and concentration of $\mathrm{N}$ in shoot, at both sites.

The interaction effect of rate and time of $\mathrm{N}$ application had significant influence on the days to maturity, 1000-kernels weight, number of effective tillers per plant, grain nitrogen uptake, straw nitrogen uptake and total nitrogen uptake at both sites. The highest number of effective tillers per plant was obtained at the highest $\mathrm{N}$ application rates of $138 \mathrm{~kg} \mathrm{ha}^{-1}$. $\mathrm{N}$ application in three times split $(1 / 4$ at planting $+1 / 2$ at mid-tillering and $1 / 4$ at anthesis) resulted in highest number of effective tillers per plant (7.05 and 6.01) at Haramaya and Meta, respectively.

The maximum number of days to physiological maturity (110 days) was observed when $138 \mathrm{~kg} \mathrm{~N}^{-1}$ and $115 \mathrm{~kg} \mathrm{~N} \mathrm{ha}^{-1}$ were applied in three splits of $1 / 4^{\text {th }}$ of the dose at planting, $1 / 2$ at mid-tillering and $1 / 4^{\text {th }}$ at anthesis and two splits of $1 / 2$ at mid-tillering and $1 / 2$ at anthesis, respectively. While the lowest days to physiological maturity (105.7 days) was recorded from $46 \mathrm{~kg} \mathrm{~N} \mathrm{ha}^{-1}$ with two split applications $(1 / 2$ at planting and $1 / 2$ at mid-tillering) at Haramaya. Whereas the maximum number of days to physiological maturity (107 days) was observed when 138 $\mathrm{kg} \mathrm{N} \mathrm{ha}{ }^{-1}$ was applied in three splits of $1 / 4^{\text {th }}$ of the dose at planting, $1 / 2$ at mid-tillering and $1 / 4^{\text {th }}$ at anthesis, however, it was statistically on par with $115 \mathrm{~kg} \mathrm{~N} \mathrm{ha}^{-1}$ at two splits $1 / 2$ at mid-tillering and $1 / 2$ at anthesis. While the lowest days to physiological maturity (102.7 days) was recorded from $46 \mathrm{~kg} \mathrm{~N} \mathrm{ha}^{-1}$ with two split applications $(1 / 2$ at planting and $1 / 2$ at mid-tillering) at Meta.

The highest 1000-kernels weight (51.00 g) was obtained at combination of $138 \mathrm{~N} \mathrm{~kg} \mathrm{ha}^{-1}$ and the two split applications ( $1 / 2$ at mid-tillering and $1 / 2$ at anthesis), and the lowest 1000 -kernels weight (42.08 g) was obtained with $46 \mathrm{~kg} \mathrm{~N} \mathrm{ha}^{-1}$ application of $\mathrm{N}$, with two split applications ( $1 / 2$ at planting and $1 / 2$ at mid-tillering) at Haramaya. Whereas the highest 1000 -kernels weight $(51.99 \mathrm{~g})$ was obtained at combination of $138 \mathrm{~kg} \mathrm{~N} \mathrm{ha}^{-1}$ and the three split applications $\left(1 / 3^{\text {rd }}\right.$ at planting $+1 / 3^{\text {rd }}$ at mid-tillering $+1 / 3^{\text {rd }}$ at anthesis), and the lowest 1000 -kernels weight (45.31 g) was obtained with $46 \mathrm{~kg} \mathrm{~N} \mathrm{ha}^{-1}$ application of $\mathrm{N}$, with three split applications $\left(1 / 3^{\text {rd }}\right.$ at planting $+1 / 3^{\text {rd }}$ at mid-tillering $+1 / 3^{\text {rd }}$ at anthesis). Thus, increasing the rate of nitrogen from 0 to $138 \mathrm{~kg} \mathrm{~N} \mathrm{ha}^{-1}$ increased 1000 kernels weight significantly by about $9.12 \%$ at Meta.

The highest grain uptake of nitrogen $\left(77.63 \mathrm{~kg} \mathrm{~N} \mathrm{ha}^{-1}\right)$ was recorded at three splitting $\left(1 / 4^{\text {th }}\right.$ at planting $+1 / 2$ at mid-tillering $+1 / 4^{\text {th }}$ at anthesis) for $138 \mathrm{~kg} \mathrm{~N} \mathrm{ha}^{-1}$ while the lowest grain uptake of nitrogen $\left(28.79 \mathrm{~kg} \mathrm{~N} \mathrm{ha}^{-1}\right)$ by bread wheat was recorded at three splitting $\left(1 / 3^{\text {rd }}\right.$ at planting $+1 / 3^{\text {rd }}$ at mid-tillering $+1 / 3^{\text {rd }}$ at anthesis $)$ for $46 \mathrm{~kg} \mathrm{~N}$ $\mathrm{ha}^{-1}$ at Haramaya. Whereas, the highest grain uptake of nitrogen $\left(86.64 \mathrm{~kg} \mathrm{~N} \mathrm{ha}^{-1}\right)$ was recorded at three splitting $\left(1 / 4^{\text {th }}\right.$ dose planting $+1 / 2$ at mid-tillering $+1 / 4^{\text {th }}$ at anthesis) for $138 \mathrm{~kg} \mathrm{ha}^{-1}$ while the lowest grain uptake of nitrogen $\left(38.87 \mathrm{~kg} \mathrm{~N} \mathrm{ha}^{-1}\right)$ by bread wheat was recorded at three splitting $\left({ }^{1} / 3^{\text {rd }}\right.$ dose at planting $+1 / 3^{\text {rd }}$ dose at mid-tillering $+1 / 3^{\text {rd }}$ dose at anthesis) for $46 \mathrm{~kg} \mathrm{~N} \mathrm{ha}^{-1}$ at Meta.

The highest straw $\mathrm{N}$ uptake for the bread wheat $\left(76.80 \mathrm{~kg} \mathrm{~N} \mathrm{ha}^{-1}\right)$ was recorded at two split applications ( $1 / 2$ at mid-tillering $+1 / 2$ at anthesis) for $138 \mathrm{~kg} \mathrm{~N} \mathrm{ha}^{-1}$, however, it was statistically at par with splitting of $1 / 2$ at planting $+1 / 2$ at mid-tillering and $1 / 4^{\text {th }}$ at planting $+1 / 2$ at mid-tillering $+1 / 4^{\text {th }}$ at anthesis whereas the lowest straw $\mathrm{N}$ uptake for bread wheat $\left(47.00 \mathrm{~kg} \mathrm{ha}^{-1}\right)$ was recorded at three time splitting $\left(1 / 3^{\text {rd }}\right.$ at planting $+1 / 3^{\text {rd }}$ at mid-tillering $+1 / 3^{\text {rd }}$ at anthesis) for $46 \mathrm{~kg} \mathrm{~N} \mathrm{ha}^{-1}$ at Haramaya. On the other hand, the highest straw $\mathrm{N}$ uptake for the bread wheat (42.14 $\left.\mathrm{kg} \mathrm{ha}^{-1}\right)$ was recorded at three splitting $\left(1 / 4^{\text {th }}\right.$ at planting $+1 / 2$ at mid-tillering $+1 / 4^{\text {th }}$ at anthesis $)$ for $138 \mathrm{~kg} \mathrm{ha}{ }^{-1}$ whereas the lowest straw $\mathrm{N}$ uptake for bread wheat $\left(21.27 \mathrm{~kg} \mathrm{ha}^{-1}\right)$ was recorded at three time splitting $\left({ }^{1} / 3^{\mathrm{rd}}\right.$ at planting + $1 / 3^{\text {rd }}$ at mid-tillering $+1 / 3^{\text {rd }}$ at anthesis) for $46 \mathrm{~kg} \mathrm{~N} \mathrm{ha}^{-1}$ at Meta.

In general, plots received $138 \mathrm{~kg} \mathrm{~N} \mathrm{ha}^{-1}$ in two splits $(1 / 2$ dose at planting $+1 / 2$ at anthesis $)$ produced high plant height and at three splits $\left(1 / 4^{\text {th }}\right.$ at planting $+1 / 2$ at mid-tillering $+1 / 4^{\text {th }}$ at anthesis) produced high spike length at Haramaya. On the other hand, plots treated with $138 \mathrm{~kg} \mathrm{~N} \mathrm{ha}^{-1}$ produced high grain and biomass yield at both sites. In general, at Haramaya, plots treated with 46 and $115 \mathrm{~kg} \mathrm{~N} \mathrm{ha}^{-1}$ at two equal splits $(1 / 2$ dose at mid-tillering 
$+1 / 2$ at anthesis) produced optimum grain yields, coupled with the best economic benefit or profitability. Therefore, this treatment can be suggested for the farmers in the study area instead of using $64 \mathrm{~kg} \mathrm{~N} \mathrm{ha}^{-1}$ applied full dose at planting. Whereas, at Meta, plots treated with 46 and $92 \mathrm{~kg} \mathrm{~N} \mathrm{ha}^{-1}$ at two equal splits $(1 / 2$ dose at mid-tillering $+1 / 2$ at anthesis) and at three splits $\left(1 / 4^{\text {th }}\right.$ at planting $+1 / 2$ at mid-tillering $+1 / 4^{\text {th }}$ at anthesis $)$, respectively produced optimum grain yields, coupled with the best economic benefit or profitability. Therefore, this treatment can be suggested for the farmers in the study area. However, since the current results are from a one season experiment, conducting the field experiments at least for one more season is recommended in order to confirm the current results.

\section{References}

American Association Cereal Chemists, 2000. Approved Methods of the American Association Chemists. American Association of Cereal Chemists, Inc., St. Paul, Minnesota.

Amsal T., Tanner, D.G. and Getinet G. 1995. Improvement in yield of bread wheat cultivars released in Ethiopia from 1949 to 1987. African Crop Science Journal 3: 41-49.

Ayoub, M., Guertin, S., Lussier, S. and Smith, D.L. 1994. Timing and levels of nitrogen fertility effects on spring wheat. Crop Sci. 34: 748-750.

Ayoub, M., Guertin, S. And Smith, D.L. 1995. Nitrogen fertilizer rate and timing effect on bread wheat protein in eastern Canada. Crop Sci. 174: 334-349.

Bekele A. 1991. Biochemical aspects of wheat in human nutrition. pp. 341-352. Ninth Regional Wheat Workshop for Eastern Central and South Africa, Addis Ababa, Ethiopia, 18-24 March 1991, CIMMYT.

Bekele G., Amanuel G. and Getinet G. 1993. Wheat production and research in Ethiopia constraint and sustainability, pp. 18-25, In: D.G. Tanner, (ed.). Developing sustainable wheat production systems. The eight regional wheat workshops for Eastern, Central and Southern Africa, Kampala, Uganda. June 7-10, 1993.

Bekele H., Verkuiji, H., Mawangi, W. and Tanner, D.G. 2000. Adaptation of improved wheat technologies in Addaba and Dodola Woreda of the Bale highlands of Ethiopia. EARO /CIMMYT, Addis Ababa, Ethiopia.

Botella, M.A., Cerda, A.C. and Lips, S.H. 1993. Dry matter production, yield and allocation of carbon-14 assimilate by wheat as affected by nitrogen source and salinity. Agronomy Journal 85 (5): 1044-1049.

Central Statistical Authority (CSA), 2004. Agricultural survey sample. Report on area and production of crops (private peasant holdings, meher season). Statistical Bulletin 33, Addis Ababa, Ethiopia.

Central Statistical Agency (CSA), 2012. Agricultural sample survey 2012/13. Report on area production of crops (private peasant holdings, Meher Season). The FDRE statistical bulletin Vol. 391, Addis Ababa, Ethiopia, 79 p.

CIMMYT. 1988. From Agronomic Data to Farmer Recommendations: An Economics Training Manual. Completely revised edition. Mexico, DF. 79p.

CIMMYT (International Centre for Maize and Wheat Improvement). 2005. Sounding the Alarm on Global Stem Rust. An assessment of race Ug99 in Kenya and Ethiopia and the potential for impact in neighbouring regions and beyond. Prepared by the expert panel on the stem rust outbreak in Eastern Africa. 29 May 2005. CIMMYT, Mexico

Donald, L.S. 2004. Understanding and reducing lodging in cereals. Advance in Agronomy. 84: 217-271.

Ejaz H., Alishah, W., Shed, A.A., Hayat, F. and Bakht, J. 2002. Yield and yield components of wheat as affected by different planting dates, seed rates and nitrogen levels. Asian Journal of plant science. 1 (5): 502-506

FAO (Food and Agriculture Organization of the United Nations), 2000. Fertilizers and Their Use. $4^{\text {th }}$ edition. International Fertilizer Industry Association. Rome, Italy. 164p.

Getachew F. 2004. Soil characterization and bread wheat (Triticum aestivum L.) response to N and P fertilizatoin. MSc Thesis, Alemaya University, Alemaya, Ethiopia.

Haile., Nigussie D. and Ayana A. 2012. Nitrogen use efficiency of bread wheat: Effects of nitrogen rate and time of application. Journal of Soil Science and Plant Nutrition 12 (3): 389-409.

Holmburg, J. 2000. A welcoming speech. pp. 1-5. In: The Eleventh Regional Wheat Workshop for Eastern, Central and Southern Africa. CIMMYT, Addis Ababa, Ethiopia.

Hoveland, C.S. 1980. Crop Quality, Storage and Utilization. American Society of Agronomy, and Crop Science Society of America, Madison, Wisconsin, USA.

Hussain, M.I., Shah, S.H. 2002. Growth, yield and quality response of three wheat (Triticum aestivum L.) varieties to different levels of N, P and K. Int. Journal of Agriculture and Biology. 4 (3): 362-364.

Iqtidar, H., Muhammad, A. K., Ejaz, A. K. 2006. Bread wheat varieties as influenced by different nitrogen levels. Journal of Zhejiang Univ. Science. 7 (1): 70-78.

Jackson, M. L. 1986. Soil Chemical Analysis. Prentice Hall Grice. Englewood Cliffs, USA. 284pp.

Khan M. A., Hussain, I. and Baloch, S. 2000. Wheat yield potential current status and future strategies. Pakistan Journal of Biological Science, 3: 82-86.

Mengel, K. and Kirkby, E.A. 1996. Principles of Plant Nutrition, Panimo Publishing Corporation, New Delhi, 
India.

Minale L., Alemayehu A. and Tilahun T. 2005. The response of bread wheat to nitrogen and phosphorous fertilizer at different agro-ecologies of North Western Ethiopia. Pp 315-319.

Ministry of Agriculture and Rural Development. 2009. Animal and Plant Health Regulatory Directorate, crop variety register, ISSUE No.12.

Olsen, S.R., Cole, C.W., Watanabe, F.S. and Dean, L.A. 1954. Estimation of available phosphorous in soils by extraction with sodium bicarbonate Circular 939, US. Department of agriculture.

Ortiz-Monasterio, J.I., Manske, G.G.B. and van Ginkel, M. 2002. Nitrogen and Phosphorus Use Efficiency. pp. 200-207. In: Reynolds, M.P., Ortiz-Monasterio, J. I.; McNab, A. (eds.). Application of physiology in wheat breeding. Mexico, D.F.: CIMMYT.

Sylvester-Bradley, R., Dampney, P.M. and Murray, A.W. 1996. The response of winter wheat to nitrogen. In: The Nitrogen Requirement of Cereals. Ministry of Agriculture, Fisheries and Food. HMSO, London. pp. 151-174.

Tanner, D.G. and Mwangi, W.M. 1992. Current issues in wheat research and production in Eastern, Central and Southern Africa: Constraints and achievements. pp. 17-36. In: Tanner, D.G., and Mwangi, W.M. (eds.). The Seventh Regional Wheat Workshop for Eastern, Central and Southern Africa. Nakuru, Kenya: CIMMYT.

Sylvester-Bradley, R., Dampney, P.M. and Murray, A.W. 1996. The response of winter wheat to nitrogen. In: The Nitrogen Requirement of Cereals. Ministry of Agriculture, Fisheries and Food. HMSO, London. pp. 151-174.

Tanner, D.G. and Mwangi, W.M. 1992. Current issues in wheat research and production in Eastern, Central and Southern Africa: Constraints and achievements. pp. 17-36. In: Tanner, D.G., and Mwangi, W.M. (eds.). The Seventh Regional Wheat Workshop for Eastern, Central and Southern Africa. Nakuru, Kenya: CIMMYT.

Tilahun G., Tanner, D.G., Tekalign M. and Getinet G., 1996. Response of rainfed bread and durum wheat to source, level and timing of nitrogen fertilizer at two Vertisol sites in Ethiopia. pp 128 - 132. In: Tanner, D.G., Payne, T. and Abdalla, O. S. (eds.). The Ninth Regional Wheat Workshop for Eastern, Central and Southern Africa, CIMMYT, Addis Ababa, Ethiopia

Tilahun G., Feyissa T., Kedir N., Genene G., Habtamu S., Ashinie B. and Abdo W. 2008. Recommendations of production management practices. pp. 39-46. In: Kedir, N., Tilahun Gelato, G. and Allo Aman. (eds.). Fifteen years achievements. Oromia Agricultural Research Institute, Sinana Agricultural Research Center, Bale Robe, Ethiopia.

Tilman, D., Cassman, K.G., Matson, P.A., Naylor, R. and Polasky, S. 2002. Agricultural sustainability and intensive production practices. Nature, 418, 671-677.

Walkley, A.J. and Black, I.A. 1954. Estimation of soil organic carbon by the chromic acid titration method. Soil Sci., 37: 29-38.

World Book Encyclopedia, 1993. Subject from W-X-Y-Z. Volume 21. pp: 268-279. 